BNL-112670-2016-JA

\title{
Controlling the active sites of Sulfur doped Carbon Nanotube-Graphene Nanolobes for Highly Efficient Oxygen Evolution and Reduction catalysis
}

\author{
Abdelhamid M. El-Sawy, Islam M. Mosa, Dong Su, Curtis J. Guild, \\ Syed Khalid, Raymond Joesten, James F. Rusling, Steven L. Suib
}

Submitted to the Advanced Energy Materials

December 2015

Center for Functional Nanomaterials

Brookhaven National Laboratory

\author{
U.S. Department of Energy \\ USDOE Office of Science (SC), \\ Basic Energy Sciences (BES) (SC-22)
}

Notice: This manuscript has been authored by employees of Brookhaven Science Associates, LLC under Contract No. DE-SC0012704 with the U.S. Department of Energy. The publisher by accepting the manuscript for publication acknowledges that the United States Government retains a non-exclusive, paid-up, irrevocable, world-wide license to publish or reproduce the published form of this manuscript, or allow others to do so, for United States Government purposes. 


\section{DISCLAIMER}

This report was prepared as an account of work sponsored by an agency of the United States Government. Neither the United States Government nor any agency thereof, nor any of their employees, nor any of their contractors, subcontractors, or their employees, makes any warranty, express or implied, or assumes any legal liability or responsibility for the accuracy, completeness, or any third party's use or the results of such use of any information, apparatus, product, or process disclosed, or represents that its use would not infringe privately owned rights. Reference herein to any specific commercial product, process, or service by trade name, trademark, manufacturer, or otherwise, does not necessarily constitute or imply its endorsement, recommendation, or favoring by the United States Government or any agency thereof or its contractors or subcontractors. The views and opinions of authors expressed herein do not necessarily state or reflect those of the United States Government or any agency thereof. 


\title{
WILEY-VCH
}

DOI: $10.1002 /$ aenm.201500966

Article type: (Full Paper)

\section{Controlling the active sites of Sulfur doped Carbon Nanotube-Graphene Nanolobes for Highly Efficient Oxygen Evolution and Reduction catalysis}

\author{
Abdelhamid M. El-Sawy, Islam M. Mosa, Dong Su, Curtis J. Guild, Syed Khalid, Raymond \\ Joesten, James F. Rusling, Steven L. Suib*
}

\author{
A.M. El-Sawy, I. M. Mosa, C. J. Guild, Prof. R. Joesten, Prof. J. F. Rusling, Prof. S. L. Suib \\ Department of Chemistry, University of Connecticut, 55 North Eagleville Road, Storrs, \\ Connecticut 06269-3060, United States, \\ A.M. El-Sawy, Prof. S. L. Suib \\ Institute of Materials Science and Department of Materials and Biomolecular Engineering, \\ University of Connecticut, Storrs, Connecticut, 06269-3222, United States \\ A.M. El-Sawy, I. M. Mosa, \\ Department of Chemistry, Faculty of Science, Tanta University, Tanta 31527, Egypt, \\ Prof. D. Su \\ Center for Functional Nanomaterials, Brookhaven National Laboratory, Upton, NY 11973 \\ United States \\ Dr. S. Khalid \\ Photon Science Directorate, Brookhaven National Laboratory, Upton, New York 11973, \\ United States, \\ Prof. S. L. Suib \\ Chemical and Biomolecular Engineering, University of Connecticut, Storrs, Connecticut, \\ 06269-3222, United States \\ Prof.S.L.S. (steven.suib@uconn.edu)
}

Keywords: Metal-free catalysis. Oxygen evolution reaction (OER). Oxygen reduction reaction (ORR). Bifunctional. Sulfur-doped Carbon nanotubes-Graphene nanolobes. 


\section{WILEY-VCH}

\section{Abstract}

Controlling active sites of metal-free catalysts is an important strategy to enhance activity of the oxygen evolution reaction (OER). Many attempts have been made to develop metal-free catalysts, but the lack of understanding of active-sites at the atomic-level has slowed the design of highly active and stable metal-free catalysts. We have developed a sequential twostep strategy to dope sulfur into carbon nanotube-graphene nanolobes. This bi-doping strategy introduced stable sulfur-carbon active-sites. Fluorescence emission of the sulfur K-edge by Xray absorption near edge spectroscopy (XANES) and scanning transmission electron microscopy electron energy loss spectroscopy (STEM-EELS) mapping and spectra confirm that increasing the incorporation of heterocyclic sulfur into the carbon ring of CNTs not only enhanced OER activity with an overpotential of $350 \mathrm{mV}$ at a current density of $10 \mathrm{~mA} \mathrm{~cm} \mathrm{~cm}^{-2}$, but also retained $100 \%$ of stability after $75 \mathrm{~h}$. The bi-doped sulfur carbon nanotube-graphene nanolobes behave like the state-of-the-art catalysts for OER but outperform those systems in terms of turnover frequency (TOF) which is two orders of magnitude greater than $(20 \% \mathrm{Ir} / \mathrm{C})$ at $400 \mathrm{mV}$ overpotential with very high mass activity $1000 \mathrm{~mA} \mathrm{~cm}^{-2}$ at $570 \mathrm{mV}$. Moreover, the sulfur bi-doping strategy showed high catalytic activity for the oxygen reduction reaction (ORR). Stable bifunctional (ORR and OER) catalysts are low cost, and light-weight bi-doped sulfur carbon nanotubes are potential candidates for next-generation metal-free regenerative fuel cells. 


\section{WILEY-VCH}

\section{Introduction}

The demand for cleaner energy has led scientists to find methods to reduce carbon dioxide emissions, utilize new sustainable resources, and decrease dependence on fossil fuels. ${ }^{[1]}$ Of the options available, hydrogen fuels have been highly investigated, with several designs of fuel cells. Currently, industrial hydrogen production is mainly derived by steam reforming of fossil hydrocarbons at elevated temperatures $\left(700-1100^{\circ} \mathrm{C}\right)$ to form low purity hydrogen with high amounts of carbonaceous byproducts which must be scrubbed or ventilated. ${ }^{[2]}$ Water is a much cleaner and sustainable source, and isolating hydrogen has been accomplished by electrocatalysis ${ }^{[3]}$ or photo-electrocatalysis, ${ }^{[4],[5]}$ although poor catalyst stability and the slow kinetics of hydrogen release at the cathode ${ }^{[3]}$ prevent these systems from commercialization. ${ }^{[6]}$ Currently oxygen evolution reaction (OER) catalysts include $\mathrm{RuO}_{2}$ which deactivates at high potential by the formation of higher valence ruthenium oxides, and $\mathrm{IrO}_{2}$, one of the rarest elements in the earth's crust (0.001 ppm). Abundant, inexpensive, and durable active alternative electrocatalysts for OER are a pressing need and are the subject of intensive research.

The use of non-noble metal oxides including perovskites ${ }^{[3],[7]}$ and spinels, such as $\mathrm{Co}_{3} \mathrm{O}_{4},{ }^{[8]} \mathrm{LiCoO}_{2},{ }^{[9]}$ and $\mathrm{Zn}_{\mathrm{x}} \mathrm{Co}_{3-\mathrm{x}} \mathrm{O}_{4}{ }^{[10]}$ can decrease the cost for OER. Intensive research has been done to understand the activity of different metal oxides having redox couples of transition metals $\mathrm{Fe}^{2+/ 3+}, \mathrm{Co}^{2+/ 3+}, \mathrm{Ni}^{2+/ 3+}$, and $\mathrm{Mn}^{3+/ 4+}$ that can act as active sites for the OER activity of these metal oxides. The presence of amorphous surfaces of metal oxides has the ability to enhance the OER activity ${ }^{[11]}$. The method of oxidation ${ }^{[12]}$, crystallinity, and $\mathrm{pH}$ range of reaction has been found to play a profound role during oxygen evolution. ${ }^{[9,13]} \cdot \mathrm{Co}_{3} \mathrm{O}_{4}$ nanoparticles have been grown on nitrogen doped graphene to increase electrical conductivity. The additions of precious metal dopants (e.g. gold) on manganese oxides ${ }^{[14]}$ and cobalt oxides $^{[15]}$ enhance their catalytic activities at the expense of cost. 


\section{WILEY-VCH}

The nature of binding and doping-induced defects is very critical to enhance the activity and stability of metal-free catalysts for oxygen evolution reactions. Carbon nanotubes or graphene doped with heteroatoms $(\mathrm{N}, \mathrm{S}, \mathrm{P} \text {, and } \mathrm{B})^{[16]}$ have been found to exhibit remarkable activity for the oxygen reduction reaction (ORR). Many computational studies have shown that doping heteroatoms on the carbon skeleton led to an increase in charge population and density and the heteroatoms act as the active sites for ORR. ${ }^{[17]}$ There are few reports about the activity of metal-free electrocatalysts for OER, due to their low activities or stabilities. ${ }^{[18]}$ The nature of OER is harsher than ORR, high current density at low overpotential was required. Y. Zhao et al. first made an OER metal-free catalyst by introducing nitrogen in the carbon, but the activity decreased after only 20 cycles. ${ }^{[18 b]}$ Films with high mass loading of a dual-doped nitrogen and oxygen hydrogel of carbon nanotubes and graphene showed low current density and stability. ${ }^{[18 \mathrm{a}]}$ Composites made by incorporation of $\mathrm{C}_{3} \mathrm{~N}_{4}$ nanosheets between the sheets of graphite and carbon nanotubes increase stability ${ }^{[19]}$. Moreover, there are recent efforts to use other doping atoms like $\mathrm{P}, \mathrm{N},{ }^{[20]}$ and $\mathrm{O} .{ }^{[21]}$ Based on these reports, low activity and stability were likely due to the nature of binding between the heteroatom and the carbon skeleton. Methods for the identification and control of the active sites of metal-free catalyst are still unclear and need a lot of intensive research in order to understand the activity and develop stable, active metal-free catalysts.

We introduce a sequential two-step or bi-doping strategy as a novel route to control the active sites of sulfur doped multiwall carbon nanotubes at the atomic scale. This unique method of doping increased the OER performance of carbon nanotubes by boosting the catalytic activity with an overpotential of $350 \mathrm{mV}$ at a current density of $10 \mathrm{~mA} \mathrm{~cm} \mathrm{~cm}^{-2}$ and results in a turnover frequency (TOF) 10 orders of magnitude greater than that of the state-ofthe-art catalyst for OER (20\% Ir/C) at $400 \mathrm{mV}$ overpotential. The stability was also enhanced and retained at $100 \%$ current density of its initial value for $5.5 \mathrm{~h}$, producing the most active and stable metal-free catalyst for OER to date. Moreover, the activity of the oxygen reduction 


\section{WILEY-VCH}

reaction (ORR) is also enhanced upon applying the bi-doping sulfur strategy and the TOF is higher by a factor of 2 than that of Pt/C, the state-of-the-art catalyst for ORR. The active sites of sulfur doped carbon nanotubes were characterized by high-resolution transmission electron microscopy (HRTEM), X-ray photoelectron spectroscopy (XPS), Cs aberration-corrected scanning transmission electron microscopy (STEM), high angle annular dark-field (HAADF) imaging, and STEM electron energy loss spectroscopy (EELS) mapping and spectra. The nature of the environment of sulfur active sites was further examined using fluorescence emission of the sulfur K-edge by X-ray absorption near edge spectroscopy (XANES). These characterization techniques were used to obtain a detailed understanding of the correlation between the active sites and the outstanding electrochemical activity of this bi-doping strategy.

\section{Results}

\subsection{Doping Paths and Products}

Sulfur-doped carbon nanotubes (CNT) were prepared as illustrated in Figure 1. Each is designated by the sulfur source, $S$ for thiourea and $S^{\prime}$ for benzyl disulfide (BDS), and by the temperature of hydrothermal treatment, $180^{\circ} \mathrm{C}$ or $1000^{\circ} \mathrm{C}$. Starting materials $(\mathrm{Ox}-\mathrm{CNT})$ were multiwall carbon nanotubes that had been partially unzipped and functionalized with oxygen by reaction with $\mathrm{H}_{2} \mathrm{SO}_{4}$ followed by $\mathrm{KMnO}_{4}$ as reported by Kosynkin et al. ${ }^{[22]}$ Sulfur was introduced to Ox-CNT either by hydrothermal treatment with thiourea at $180^{\circ} \mathrm{C}$ for $8 \mathrm{~h}$ to form the intermediate, $\mathrm{S}-\mathrm{CNT}_{180^{\circ} \mathrm{C}}$, or by pyrolytic reaction with benzyl disulfide under an $\mathrm{N}_{2}$ atmosphere at $1000^{\circ} \mathrm{C}$. Three types of S-functionalized CNTs were produced by pyrolytic treatment at $1000^{\circ} \mathrm{C}$ under an $\mathrm{N}_{2}$ atmosphere: (1) $\mathrm{S}-\mathrm{CNT}_{1000^{\circ} \mathrm{C}}$ by pyrolytic treatment of $\mathrm{S}$ -

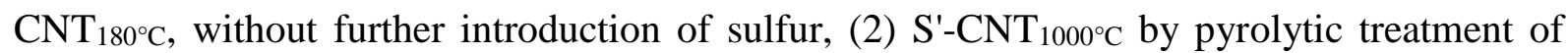
Ox-CNT with BDS, and (3) $\mathrm{S}, \mathrm{S}^{\prime}-\mathrm{CNT}_{1000^{\circ} \mathrm{C}}$ by pyrolytic treatment of $\mathrm{S}-\mathrm{CNT}_{180^{\circ} \mathrm{C}}$ with $\mathrm{BDS}$ to produce "bi-doped" CNT. The objective is to compare the total sulfur, the nature of sulfur 


\section{WILEY-VCH}

functionalization, and catalytic performance of doped CNT produced in these different processes.

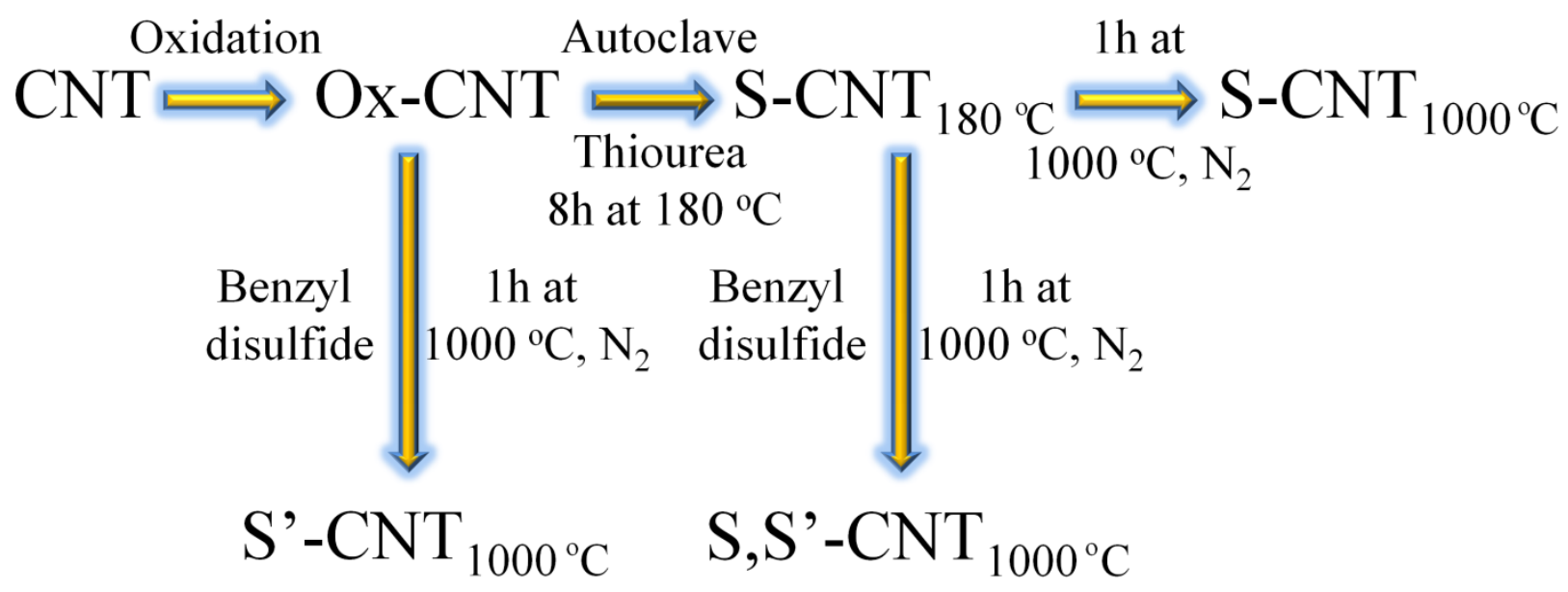

Figure 1. Illustration of the routes of bi-doping strategy. The first step oxidizes carbon nanotubes (Ox-CNT) by Hummer's method, followed by hydrothermal treatment of Ox-CNT by thiourea at $180^{\circ} \mathrm{C}$ for $8 \mathrm{~h}$ to form $\mathrm{S}-\mathrm{CNT}_{180}{ }^{\circ} \mathrm{c}$ or pyrolyzing in $\mathrm{N}_{2}$ at

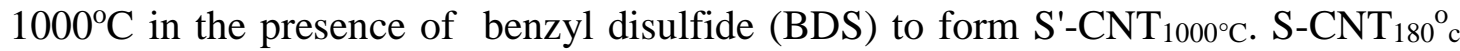
was heated in $\mathrm{N}_{2}$ at $1000^{\circ} \mathrm{C}$ to form $\mathrm{S}-\mathrm{CNT}_{1000^{\circ}} \mathrm{c}$. Further treatment under the same conditions in the presence of BDS to form sulfur bi-doped carbon nanotube-graphene nanolobes $\left(\mathrm{S}, \mathrm{S}^{\prime}-\mathrm{CNT}_{1000} \mathrm{c}\right)$.

\subsection{Material Characterization}

As supplied "pristine" multiwalled carbon nanotubes are approximately $27 \mathrm{~nm}$ in diameter. HRTEM imaging (Figure 2a, S1) shows fringes are parallel with slight undulation, and, although a few bifurcate, all are well ordered to the margin of the CNT. Upon hydrothermal treatment with thiourea, $\left(\mathrm{S}-\mathrm{CNT}_{1000^{\circ}} \mathrm{C}\right)$, a disordered surface zone, 0.4-1.5 $\mathrm{nm}$ in width, equivalent to a width of 2-4 fringes, is formed, in which the definition of the fringes is lost (Figure 2b, S2). This is interpreted as representing partial unzipping of the outer 2 to 4 layers of the MWCNT. On the second step of doping with benzyl disulfide (Figure 2c, S3) (S,S'$\mathrm{CNT}_{1000^{\circ} \mathrm{C}}$, the zone of disorder is removed, fringes while contorted, extend to the $\mathrm{CNT}$ margin, but do not everywhere lie parallel to this margin. Some nanotubes of this material 


\section{WILEY-VCH}

retain their parallel-sided geometry. Irregular lobes of fringe-free material, 2-4 $\mathrm{nm}$ in size, extend out from the margins and are interpreted as graphene sheets resulting from small scale unzipping of the outer layer. Other CNTs appear comprised of bulbous segments, with internal structure as described. Half-oval lobes comprising highly contorted fringes or, more commonly, fringe-free material make up much of the margin of the CNT (Figure 2d, S3). They may extend as much as 5-10 nm from the surface of the CNT and 10-15-nm along its length. These are interpreted as graphene layers, "peeled back", partially opening or "unzipping" the CNT. These features are analogous to the graphene nanosheets produced by the localized partial unzipping of MWCNT described by Kosynkin et. al. , ${ }^{[22]}$ Figure 1a, S1. The lobe at center right in the image of Figure 2d, S3 appears to be 4-6 graphene layers in thickness. Further increasing the ratio of BDS relative to CNT leads to a significant decrease of the integrity of the CNTs and large amounts of graphene material along with some remnants of CNT as seen in Figure S4. The SEM images of different doped carbon nanotubes have the same microstructure Figure S5. 


\section{WILEY-VCH}
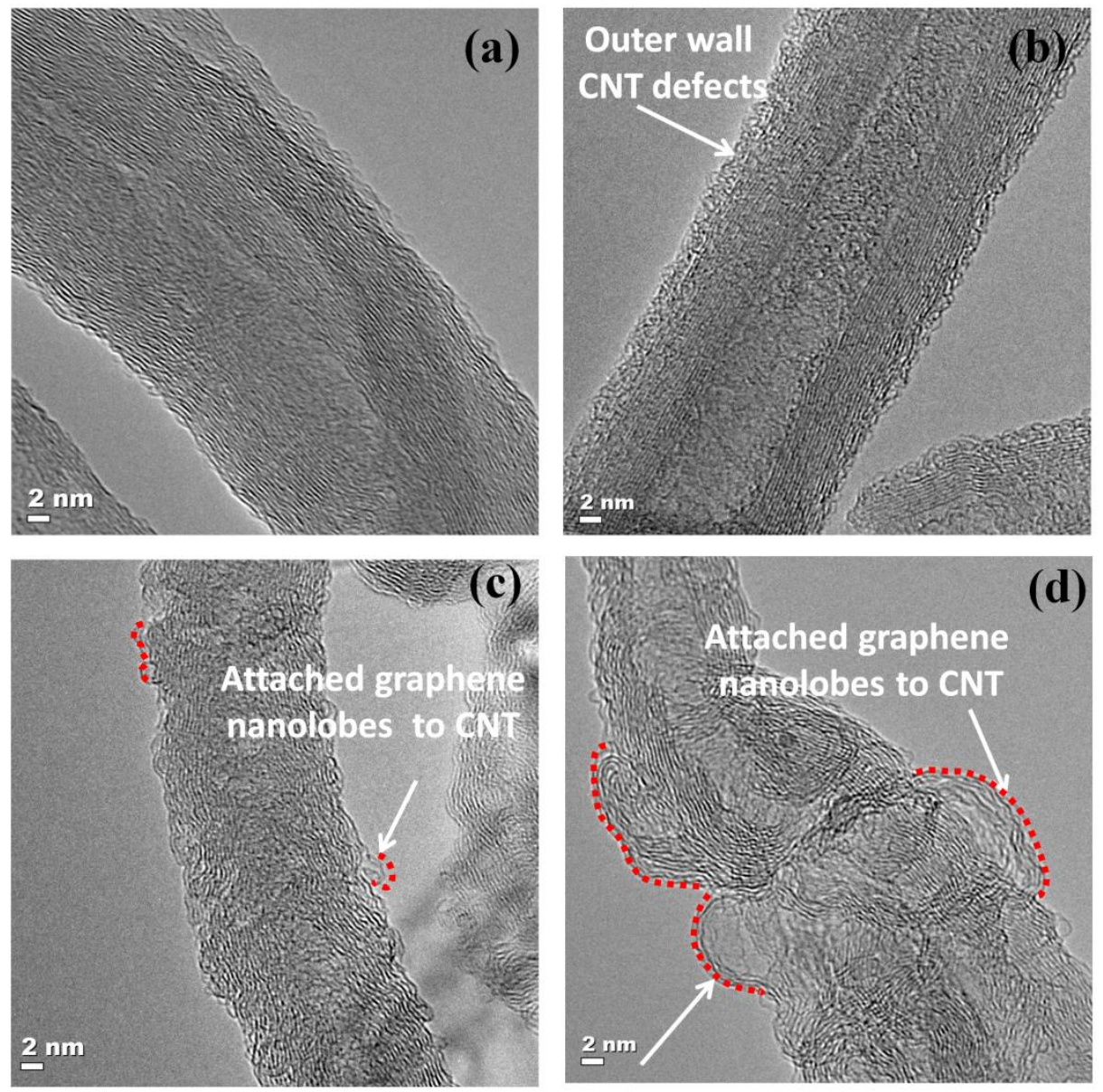

Figure 2. HRTEM images of nanotubes. (a) "pristine" nanotube showing intact wall structure, (b) sulfur doped carbon nanotube $\mathrm{S}-\mathrm{CNT}_{1000}{ }^{\circ} \mathrm{C}$ showing distortion of the outer wall of CNT (c) and (d) bi-doped CNT (S,S'-CNT $\left.1000^{\circ} \mathrm{C}\right)$ showing lobate graphene layers represented partially-opened walls of the CNT (outlined by red dotted line). 


\section{WILEY-VCH}

The nature of the sulfur doped carbon nanotubes was examined by X-ray photoelectron spectroscopy (XPS) to estimate surface concentrations of oxygen and sulfur and to identify and quantify the proportion of the electroactive sites in different sulfur doped nanotubes. The

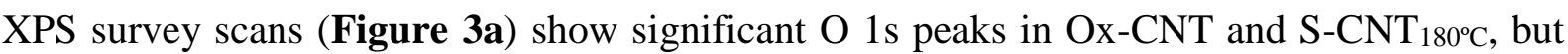
the intensity of $\mathrm{O} 1 \mathrm{~s}$ is greatly reduced with corresponding increase in the intensity of $\mathrm{C} 1 \mathrm{~s}$ in all samples treated at $1000^{\circ} \mathrm{C}$. Figure $\mathbf{3 b}$, S6 and Table S1 show that $\mathrm{S}-\mathrm{CNT}_{180^{\circ} \mathrm{C}}$ contains $17.18 \%$ oxygen. Upon heating to $1000^{\circ} \mathrm{C}$ in $\mathrm{N}_{2}$ reduces oxygen to $4.05 \%$ in $\mathrm{S}-\mathrm{CNT}_{1000^{\circ}} \mathrm{C}$. Oxygen content in $\mathrm{Ox}-\mathrm{CNT}$ reacted with $\mathrm{BDS}$ at $1000^{\circ} \mathrm{C}$ in $\mathrm{N}_{2}$ is $2.48 \%$ in both single- and bi-doped materials and also the pristine $\mathrm{CNT}$ treated at $1000^{\circ} \mathrm{C}$ means that the oxygen detected in $\mathrm{S}, \mathrm{S}^{\prime}-\mathrm{CNT}_{1000}{ }^{\circ} \mathrm{C}$ might be adsorbed $\mathrm{O}_{2}$ or $\mathrm{CO}_{2}$ from the atmosphere and this is surface oxygen physically adsorbed on the surface of CNTs not incorporated in the ring of carbons of CNTs. Energy dispersive X-Ray spectroscopy (EDX) showed negligible signal for oxygen in $\mathrm{S}, \mathrm{S}^{\prime}-\mathrm{CNT}_{1000^{\circ} \mathrm{C}}$ (Figure S7). Within analytical uncertainty, the sum of sulfur plus oxygen in $\mathrm{S}-\mathrm{CNT}_{180^{\circ} \mathrm{C}}$ is equal to the content of oxygen in Ox-CNT, suggesting that sulfur introduced to CNT surfaces by reaction with thiourea at low temperatures is bonded to sites functionalized with oxygen.

The decrease in sulfur from $1.77 \%$ on $\mathrm{S}-\mathrm{CNT}_{180^{\circ} \mathrm{C}}$ surfaces to $0.01 \%$ on $\mathrm{S}-\mathrm{CNT}_{1000^{\circ} \mathrm{C}}$ indicates that this sulfur is not strongly bonded, an inference reinforced in the analysis of $\mathrm{C} 1 \mathrm{~s}$ XPS spectra (Figure S8 and Table S3). While the concentration of sulfur introduced by hydrothermal reactions of Ox-CNT with BDS at $1000^{\circ} \mathrm{C}$ is $0.4 \%$, and treatment of $\mathrm{S}-\mathrm{CNT}_{180^{\circ} \mathrm{C}}$ at $1000^{\circ} \mathrm{C}$ reduces sulfur content to nearly zero, reaction of $\mathrm{S}-\mathrm{CNT}_{180^{\circ} \mathrm{C}}$ with $\mathrm{BDS}$ at $1000^{\circ} \mathrm{C}$ results in sulfur concentrations of $1.19 \%$ in $S, S^{\prime}-C_{N T} 1000^{\circ} \mathrm{C}$. Although the $\mathrm{S} 2 \mathrm{p}_{1 / 2}$ and $\mathrm{S} 2 \mathrm{p}_{3 / 2}$ spin-orbit doublets for sulfur are not resolved in the measured high resolution S 2p XPS peaks for $\mathrm{S}^{\prime}-\mathrm{CNT}_{1000^{\circ} \mathrm{C}}$ and $\mathrm{S}, \mathrm{S}^{\prime}-\mathrm{CNT}_{1000^{\circ} \mathrm{C}}$, a good fit to the measured spectra is obtained by deconvolution into the $2 \mathrm{p}_{1 / 2}$ and $2 \mathrm{p}_{3 / 2}$ transitions for $\mathrm{C}-\mathrm{S}-\mathrm{C}$ at 163.8 and $165.3 \mathrm{eV}$ (Figure 9c, S9 and Table S2). In addition to the contribution of C-S-C bonds, about $10 \%$ of the area of 


\section{WILEY-VCH}

the $\mathrm{S}_{2 \mathrm{p}}$ peak for $\mathrm{S}^{\prime}-\mathrm{CNT}_{1000}{ }^{\circ} \mathrm{C}$ accounts for C-SOx peak at $168.2 \mathrm{eV}$. There is no evidence for C-SOx in the bi-doped sample, consistent with all sulfur bonded to carbon in this material.

The high resolution $\mathrm{C}$ 1s peak for each of the S-doped CNT at $285 \mathrm{eV}$, is deconvoluted into five bonding components, dominated in all samples by C-C (Figure 3d and S8a-d). Oxidation of the $\mathrm{CNT}$ introduces $\mathrm{C}-\mathrm{O}, \mathrm{C}=\mathrm{O}$, and $\mathrm{COOH}$ functionalities. Concentration of these oxide and hydroxide species, expressed as percentage of total peak area, drops from about $50 \%$ in $\mathrm{Ox}-\mathrm{CNT}$ and $\mathrm{S}-\mathrm{CNT}_{180^{\circ} \mathrm{C}}$ to about $33 \%$ in materials heat treated at $1000^{\circ} \mathrm{C}$ (Table S3), while the proportions of $\mathrm{C}-\mathrm{O}: \mathrm{C}=\mathrm{O}: \mathrm{COOH}$ change from 50:32:12 in Ox-CNT to 65:20:10 in each of the $1000^{\circ} \mathrm{C}$ samples.

Presence of sulfur is recorded by C-S peak in the deconvoluted C 1s spectra. Highest

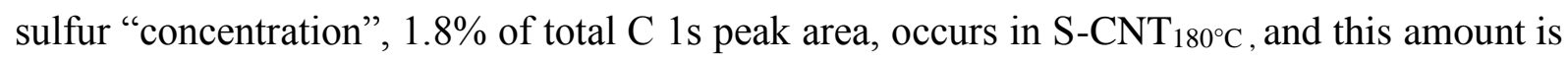
reduced to $0.7 \%$ in $\mathrm{S}_{-\mathrm{CNT}} 1000^{\circ} \mathrm{C}$. This again suggests that sulfur introduced via thiourea is not strongly bonded to the carbon mesh. The area of the C-S peak for the benzyl disulfide samples

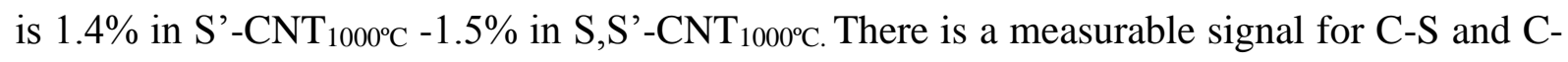
S-C bonding in the S $2 p$ and C 1s spectra for all S-doped samples, although greatly diminished in the thiourea doped sample heat treated at $1000^{\circ} \mathrm{C}$. Similarly, there is a significant decrease in the XPS signal for oxide and hydroxide functionalities in the samples heat treated at $1000^{\circ} \mathrm{C}$ compared with their values in the original oxidized CNT's and the low temperature thiourea sample. 


\section{WILEY-VCH}
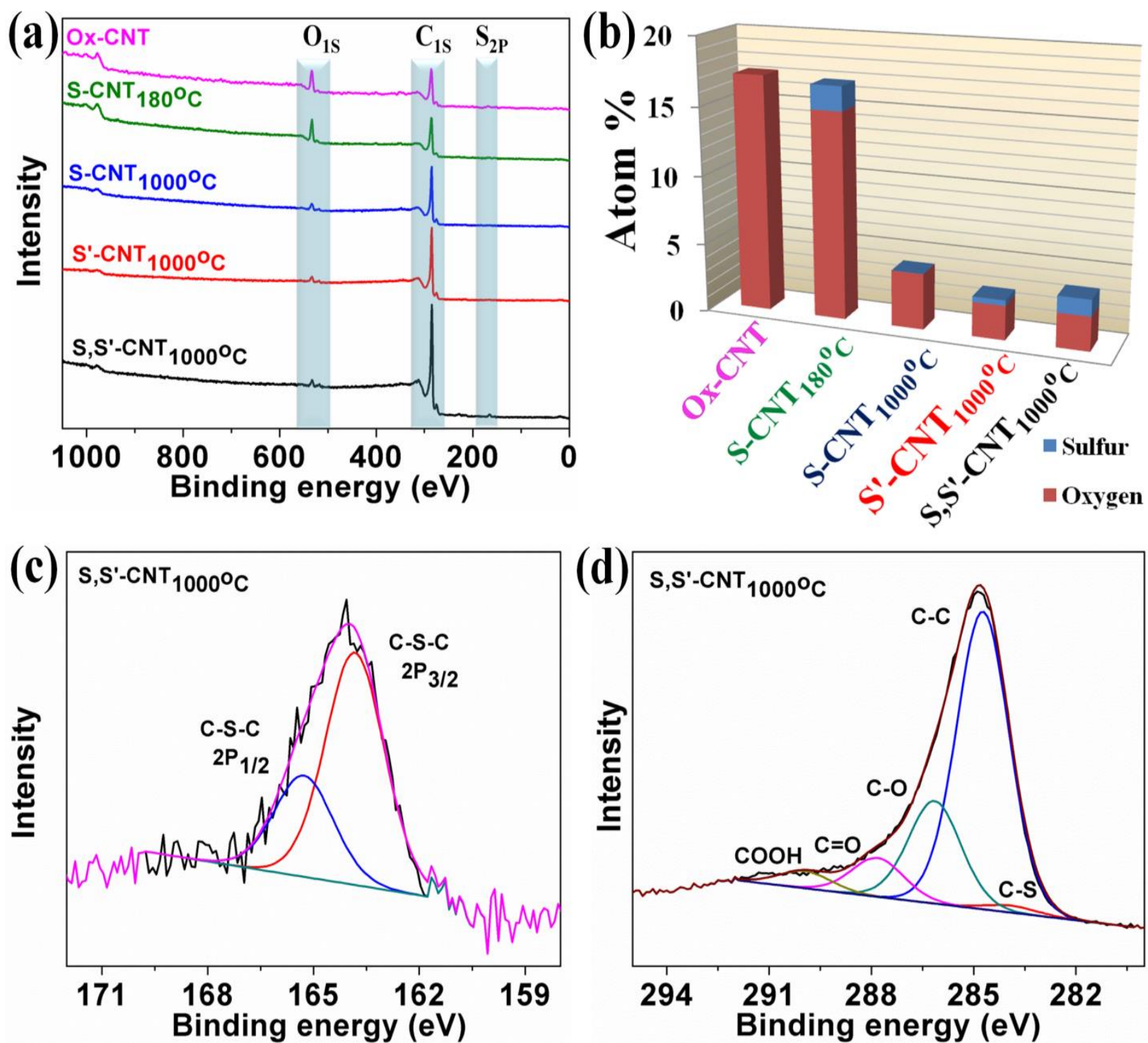

Figure 3. X-ray photoelectron spectroscopy (a) Survey XPS scans for Ox-CNT, S-

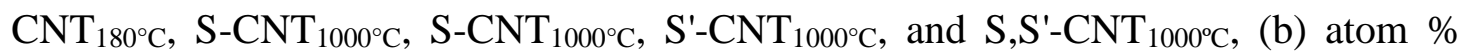
sulfur and oxygen estimated from XPS peak areas, (c) High-resolution deconvolution of the $\mathrm{S}_{2 \mathrm{p}}$ peak for $\mathrm{S}_{,} \mathrm{S}^{\prime}-\mathrm{CNT}_{1000^{\circ} \mathrm{C}}$, (d) High-resolution deconvolution of $\mathrm{C}_{1 \mathrm{~s}}$ peak for

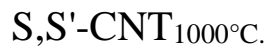

Raman spectra for pristine CNT, Ox-CNT, and all S-doped CNT show the sharp $\mathrm{I}_{\mathrm{D}}$ and $\mathrm{I}_{\mathrm{G}}$ peaks at 1350 and $1590 \mathrm{~cm}^{-1}$ characteristic of CNT's as well as the broad two-phonon pair (2D and D+G) at 2700 and $2900 \mathrm{~cm}^{-1}$ (Figure 4a). The G-peak arises from in-plane vibrations of the $\mathrm{sp}^{2}-\mathrm{C}-\mathrm{C}$ - network and in $\mathrm{CNT}$ is a measure of the order in CNT sidewalls. Disorder in the CNT sidewalls as well as bonding of heteroatoms to carbon contributes to the 


\section{WILEY-VCH}

intensity of the D-band peak. The ratio $\mathrm{I}_{\mathrm{D}}: \mathrm{I}_{\mathrm{G}}$ is a commonly cited measure of structural disorder in CNTs. ${ }^{[23]}$ Disorder introduced on functionalizing the surface of CNT increases the $\mathrm{I}_{\mathrm{D}}: \mathrm{I}_{\mathrm{G}}$ from 1.05 in Pristine CNT to 1.11 in Ox-CNT. Bonding of sulfur to the surface further increases the $\mathrm{I}_{\mathrm{D}}: \mathrm{I}_{\mathrm{G}}$ from 1.12 and 1.14 in $\mathrm{S}^{\prime}-\mathrm{CNT}_{1000^{\circ} \mathrm{C}}$ and $\mathrm{S}^{-} \mathrm{CNT}_{1000^{\circ} \mathrm{C}}$ to 1.19 in $\mathrm{S}, \mathrm{S}^{\prime}-$ $\mathrm{CNT}_{1000^{\circ} \mathrm{C}}$

Exploring the sulfur content is very difficult by XPS, and other techniques are often unable to provide precise information about the nature of sulfur in each step of doping. The sulfur K-edge XANES is the ideal tool for the identification of sulfur species bonded to the CNTs based on an edge shift of up to $12 \mathrm{eV}$ over the range in oxidation state of sulfur from $2^{-}$ to $6^{+} .^{[24]}$ K-edge XANES spectra for S-doped CNT show two broad peaks representing reduced $\left(\mathrm{S}_{\mathrm{Red}}\right)$ and oxidized $\left(\mathrm{S}_{\mathrm{Ox}}\right)$ sulfur species (Figure $\left.\mathbf{4 b}\right)$. The $\mathrm{S}_{\mathrm{Red}}$ peak can be split into contributions from three different functionalities: exocyclic sulfur (sulfur out of the carbon six-member ring), heterocyclic sulfur (sulfur in the ring), and sulfoxide (-SO-). The Sox peak can be split into sulfone $\left(-\mathrm{SO}_{2}-\right)$ and sulfonate $\left(-\mathrm{SO}_{3}\right)$ contributions. ${ }^{[24]}$ The XANES spectrum of CNT with thiourea $\left(\mathrm{S}-\mathrm{CNT}_{180^{\circ} \mathrm{C}}\right)$ shows peaks for both exo- and heterocyclic sulfur in the reduced region and sulfone in the oxidized region. The XANES spectrum of CNT treated with benzyl disulfide $\left(\mathrm{S}^{\prime}-\mathrm{CNT}_{1000^{\circ} \mathrm{C}}\right)$ has peaks for heterocyclic sulfur and sulfoxide and a probable mixture of sulfone and sulfonate in the oxidized region. The signal for bi-doped CNT (S,S'$\left.\mathrm{CNT}_{1000^{\circ}} \mathrm{C}\right)$ appears to be dominated by heterocyclic sulfur in the reduced region and the sulfone + sulfonate mix in the oxidized region. Potential heterocyclic sulfur moieties in S,S'$\mathrm{CNT}_{1000^{\circ} \mathrm{C}}$ include thiophene and thiopyran. The normalized intensity of the $\mathrm{S}_{\mathrm{Red}}$ peak

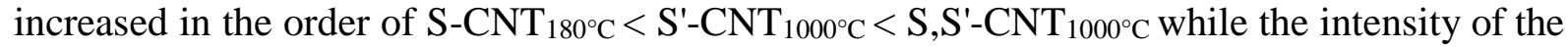
Sox peak decreased in the same order. 


\section{WILEY-VCH}
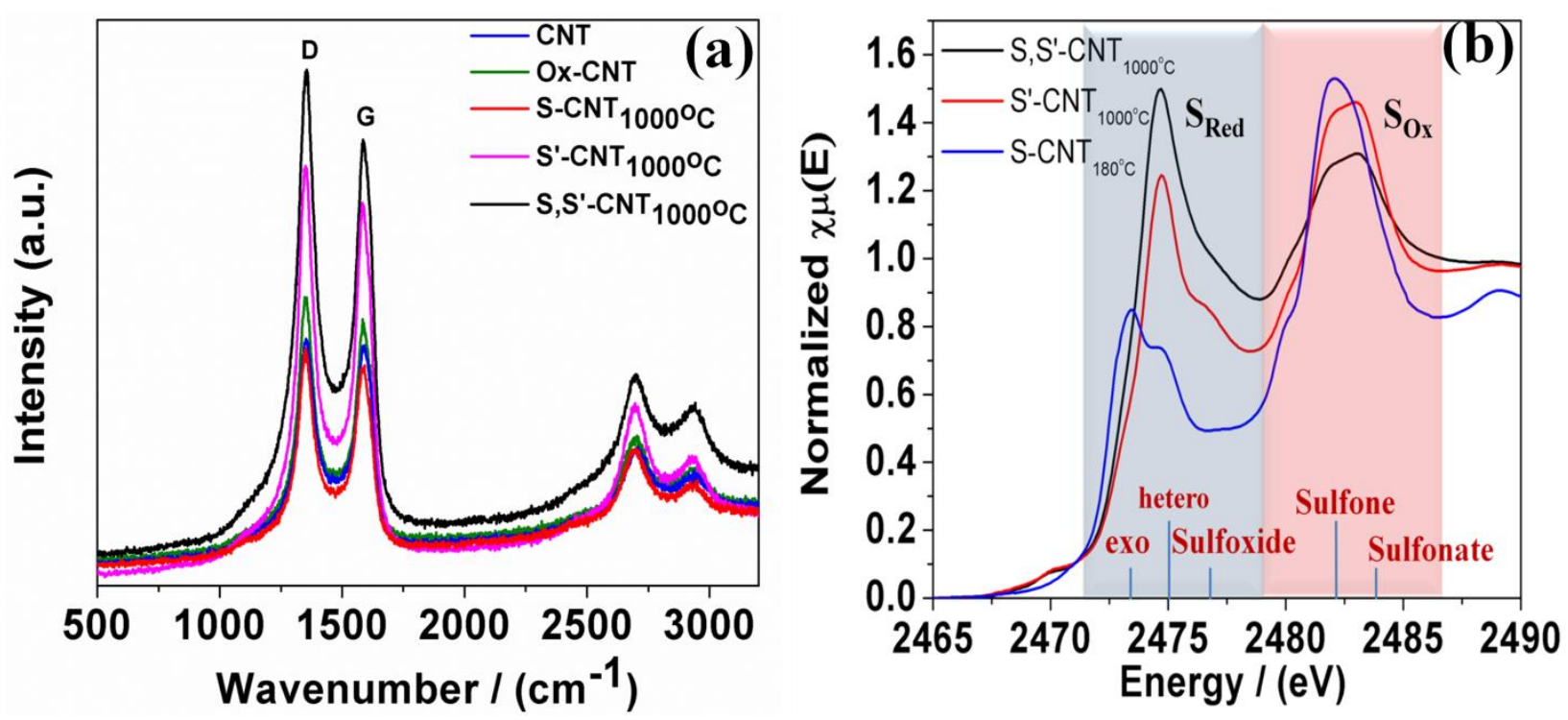

Figure 4. (a) Raman spectra for Pristine, oxidized, and S-doped CNT, (b) Sulfur K-edge Xray absorption near edge spectroscopy (XANES). The $\mathrm{I}_{\mathrm{D}} / \mathrm{I}_{\mathrm{G}}$ ratio increased by increasing the doping of sulfur (b) Sulfur K-edge X-ray absorption near edge spectroscopy (XANES) showing the change of nature of atoms surrounding the sulfur. 


\section{WILEY-VCH}

The chemical microstructure of $\mathrm{S}, \mathrm{S}^{\prime}-\mathrm{CNT}_{1000^{\circ}} \mathrm{C}$, was investigated using High-Angle Annular Dark-Field (HAADF-STEM) and STEM-EELS Figure 5a, S10a. The CNT shows lobate structures extending outward, 5-7 $\mathrm{nm}$ from the margins, interpreted in the HRTEM study as graphene sheets resulting from small scale unzipping of the outer layers. Contrast in these images is directly related to the atomic number. ${ }^{[23,25]}$ Mottling in the image reflects local variability in sulfur and carbon content. Element mapping was performed by STEM-EELS to determine the spatial distribution of sulfur on the carbon nanotubes. Figure 5b-d, S10b-d show EELS mapping of carbon (green), sulfur (red), and the two superimposed (yellow sulfur on green carbon). Sulfur is more or less uniformly distributed over the surface of the carbon nanotube, although "hot spots" occur which is different from previously reported sulfur terminated graphene nanoribbons. ${ }^{[26]}$

Figure 5f-g depict the HAADF-STEM image and STEM-EELS line scan across a CNT. The apparent higher concentration of carbon at margins of the CNT and dip at the center reflect the fact that the EELS spectrum is collected from the whole thickness of the CNT. There is greater energy loss along the longer path within CNT walls compared with that cutting through multi-layers at the top and bottom of the CNT and its hollow interior. The sulfur signal is noisy, but the concentration appears uniform from edge to edge. The lack of the edge effect seen in the carbon signal confirms that sulfur is on the surface of the CNT and not in the interior. These observations confirm that the sulfur hetero atoms have a uniform distribution on the CNT and nanolobes representing partially unzipped CNT which make these active sites more accessible to the reaction medium. The EELS spectrum (Figure 5h) inside the sulfur bidoped nanotube compared with surface and pristine material showed a S-L edge peak $(163-237 \mathrm{eV})^{[27]}$ that provided further evidence of sulfur functionalization on the carbon. EELS of the carbon K-edge consists of the characteristic peaks for $\pi^{*}$ (corresponding to $1 \mathrm{~s} \rightarrow \pi^{*}$ of $\mathrm{sp}^{2}$ hybridization) at $287 \mathrm{eV}$ and $\sigma^{*}$ (corresponding to $1 \mathrm{~s} \rightarrow \sigma^{*}$ of $\mathrm{sp}^{3}$ hybridization) transitions at $295 \mathrm{eV}$. 


\section{WILEY-VCH}

(a)
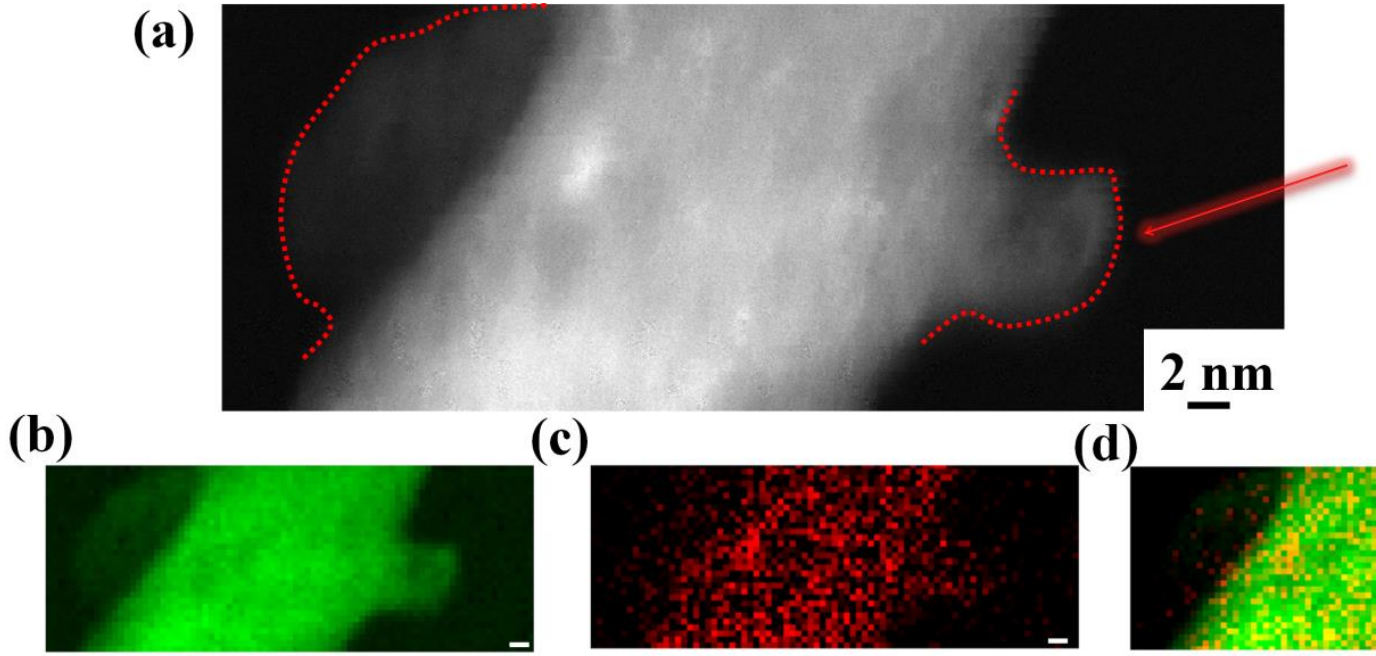

Attached

Graphene nanolobes

(c) (d)
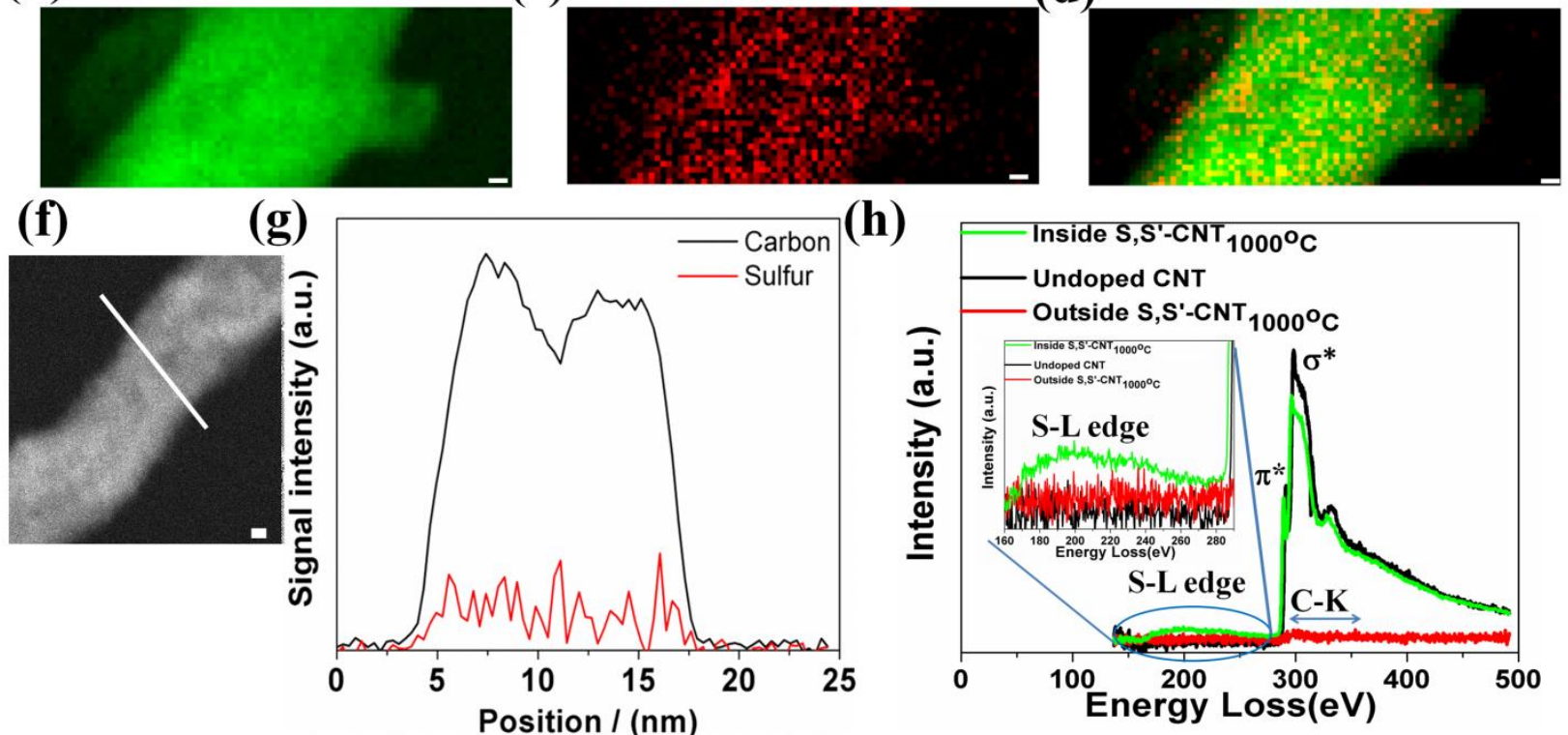

(h)

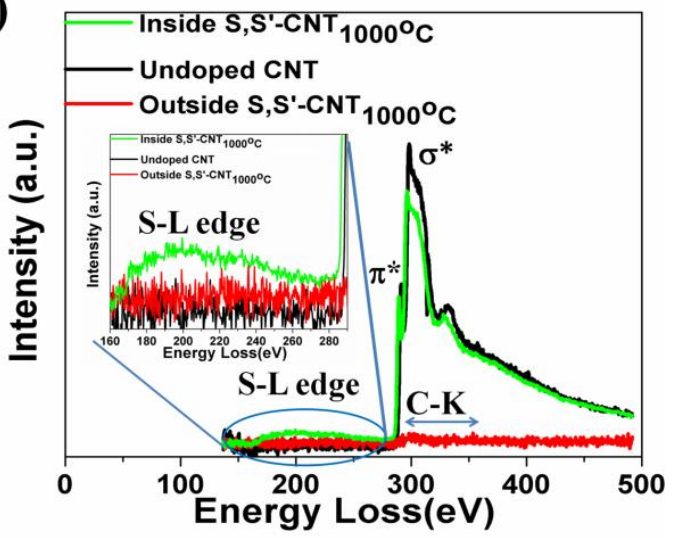

Figure 5. Scanning transmission electron microscopy (a) HAADF-STEM image of bi-doped sulfur carbon nanotube $\left(\mathrm{S}, \mathrm{S}^{\prime}-\mathrm{CNT}_{1000^{\circ} \mathrm{C}}\right)$ red dotted lines are used to mark the graphene nanolobes. EELS mapping of (b) carbon, (c) sulfur and (d) the superimposed pattern of carbon (green) and sulfur (yellow). (f) HAADF-STEM image of S,S'-CNT $1000^{\circ} \mathrm{C}$ with line-scan profile (g) cross sectional distribution of carbon and sulfur on the carbon nanotube (h) EELS spectrum containing C-K and S-L edges. (All scale bars are $2 \mathrm{~nm}$ ). 


\section{WILEY-VCH}

\subsection{Oxygen Evolution Reaction (OER)}

The electrochemical catalytic activity of bi-doped carbon nanotubes $\left(\mathrm{S}, \mathrm{S}^{\prime}-\mathrm{CNT}_{\left.1000^{\circ} \mathrm{C}\right)}\right.$ was examined with a rotating disc electrode $(\mathrm{RDE})$ in $1 \mathrm{M} \mathrm{KOH}$ electrolyte saturated by $\mathrm{O}_{2}$ at room temperature $\left(25^{\circ} \mathrm{C}\right)$. The performance of bi-doped sulfur carbon nanotubes at 1600 r.p.m. showed remarkable current density compared to $20 \% \mathrm{Ir} / \mathrm{C}$ in the oxygen evolution reaction (OER) as shown in Figure 6a. Linear sweep voltammetry (LSV) showed the superior current density activity of the bi-doped sulfur carbon nanotubes. The catalytic activities of the monodoped sulfur carbon nanotubes and other undoped carbon nanotubes with different strategies are compared in Figure 6b, S11. The cyclic voltammetry of S,S'-CNT $1000^{\circ} \mathrm{C}$ (Figure S12) revealed the absence of any capacitance which was also supported by increasing the scan rate of the LSV from 5 to $200 \mathrm{mVs}^{-1}$ without changing the current density in a wide range of overpotential (420-570 mV) (Figure $\mathbf{S 1 3}$ and the inset figure). The catalytic activity of S,S'$\mathrm{CNT}_{1000^{\circ} \mathrm{C} \text { shows that the overpotential at } 10 \mathrm{~mA} \mathrm{~cm}}{ }^{-2}$, which is required for solar operation, is $350 \mathrm{mV}$. This is the most active metal-free catalyst system for aqueous alkaline oxygen reduction reaction to date. ${ }^{[18 b, 19,28]}$ The activity of different bi-doped and mono-doped carbon nanotubes compared to Ir/C followed this order $\mathrm{S}, \mathrm{S}^{\prime}-\mathrm{CNT}_{1000^{\circ} \mathrm{C}}>20 \% \mathrm{wt}$. Ir/C $>\mathrm{S}^{\prime}-\mathrm{CNT}_{1000^{\circ} \mathrm{C}}$ $>\mathrm{S}-\mathrm{CNT}_{1000^{\circ} \mathrm{C}}>\mathrm{S}-\mathrm{CNT}_{180^{\circ} \mathrm{C}}>20 \%$ wt. Pt/C. The OER parameters are summarized in Table 1.

Additional electrochemical characterization was used to explore the superior activity of the sulfur bi-doped carbon nanotubes. The activity of $\mathrm{S}, \mathrm{S}^{\prime}-\mathrm{CNT}_{1000^{\circ} \mathrm{C}}$ was probed by using electrochemical impedance spectroscopy (EIS). The charge transfer resistance $\left(\mathrm{R}_{\mathrm{CT}}\right)$ was obtained from the fitted equivalent circuit. The $\mathrm{S}, \mathrm{S}^{\prime}-\mathrm{CNT}_{1000^{\circ} \mathrm{C}}$ has the smallest charge transfer resistance of all studied systems which shows the highest standard rate constant $\left(\mathrm{k}^{\circ}=8.63 \mathrm{x}\right.$ $10^{-3} \mathrm{~cm} \mathrm{~s}^{-1}$ ) and the fastest electron transfer rate among studied catalysts due to the highly accessible sulfur active sites that facilitated the oxygen evolution (Figure 6d). The Tafel slope of S, $\mathrm{S}^{\prime}-\mathrm{CNT}_{1000^{\circ} \mathrm{C}}\left(95 \mathrm{mV} \mathrm{dec}{ }^{-1}\right)$ was also the smallest compared to $20 \% \mathrm{Ir} / \mathrm{C}(120 \mathrm{mV}$ 


\section{WILEY-VCH}

$\operatorname{dec}^{-1}$ ) and other mono-doped sulfur carbon nanotubes (Figure 6c). The faradic efficiency of $\mathrm{S}, \mathrm{S}^{\prime}-\mathrm{CNT} 1000^{\circ} \mathrm{C}$ is $99.4 \%$ Figure $\mathbf{S 1 4}$. For further activity assessment of $\mathrm{S}, \mathrm{S}^{\prime}-\mathrm{CNT}_{1000^{\circ} \mathrm{C}}$, the mass activities and turnover frequencies (TOF) at $\eta=400 \mathrm{mV}$ were calculated (Figure S15, Table 1). The TOF for $S, S^{\prime}-C_{N T} 1000^{\circ} \mathrm{C}$ is very high $\left(0.13 \mathrm{~s}^{-1}\right)$ at $\eta=400 \mathrm{mV}$ relative to $20 \%$ Ir/C $\left(0.03 \mathrm{~s}^{-1}\right)$. The TOF value for $\mathrm{S}, \mathrm{S}^{\prime}-\mathrm{CNT}_{1000^{\circ} \mathrm{C}}$ increased until reaching 5.6 orders of magnitude of $20 \% \mathrm{Ir} / \mathrm{C}$ at $\eta=570 \mathrm{mV}$ with a value $0.9 \mathrm{~s}^{-1}$ Figure S16. The newly developed bi-doped sulfur carbon nanotube has a very high mass activity reaching $1000 \mathrm{~mA} \mathrm{~g}^{-1}$ at $\eta=$ $570 \mathrm{mV}$ Figure 7a which indicates the excellent performance of the developed new strategy of bi-doped sulfur carbon nanotubes.

The outstanding performance of $\mathrm{S}, \mathrm{S}^{\prime}-\mathrm{CNT}_{1000^{\circ} \mathrm{C}}$ and the stability of the metal-free catalyst are significant issues regarding the practical use of metal-free catalysts in fuel cells for water electrolysis ${ }^{[18 a,}{ }^{18 b]}$. The chronoamperometric study of $\mathrm{S}, \mathrm{S}^{\prime}-\mathrm{CNT}_{1000^{\circ} \mathrm{C}}$ shows remarkable stability for OER at a current density of $10 \mathrm{~mA} \mathrm{~cm}$ (Figure 7b). The S,S'$\mathrm{CNT}_{1000}{ }^{\circ} \mathrm{C}$ maintained $100 \%$ of its initial current density after $75 \mathrm{~h}$ and can be considered the most durable metal-free catalyst reported until now (Table S4). Moreover, the materials exhibit self-healing when the current density increased by $20 \%$ from its initial value after 5.5 h. In contrast, the current density of Ir/C dropped by $37 \%$ within $3.5 \mathrm{~h}$ under the same conditions Figure S2. In order to obtain more information about structure-stability relationships, we performed the same experiment on $\mathrm{S}-\mathrm{CNT}_{180^{\circ}} \mathrm{C}$ and found the current density drastically dropped to $10 \%$ of its initial current density within $1.5 \mathrm{~h}$. 


\section{WILEY-VCH}

(a)

(c) $\mathrm{cm}^{-2}$. (b)
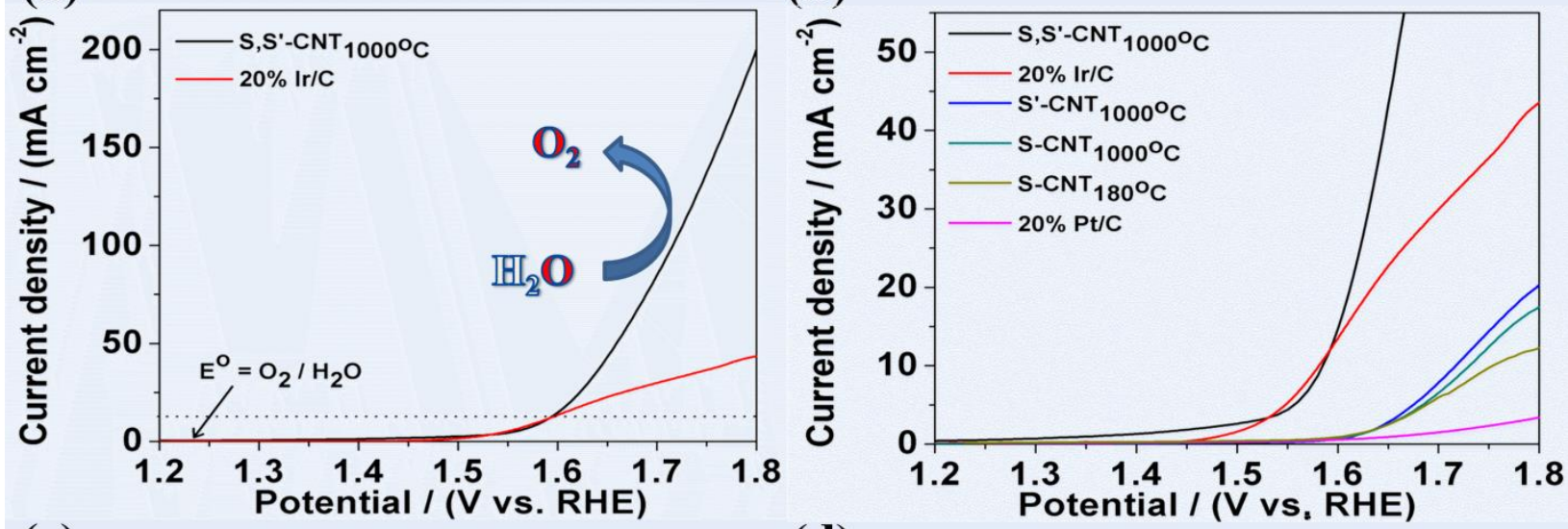

(d)

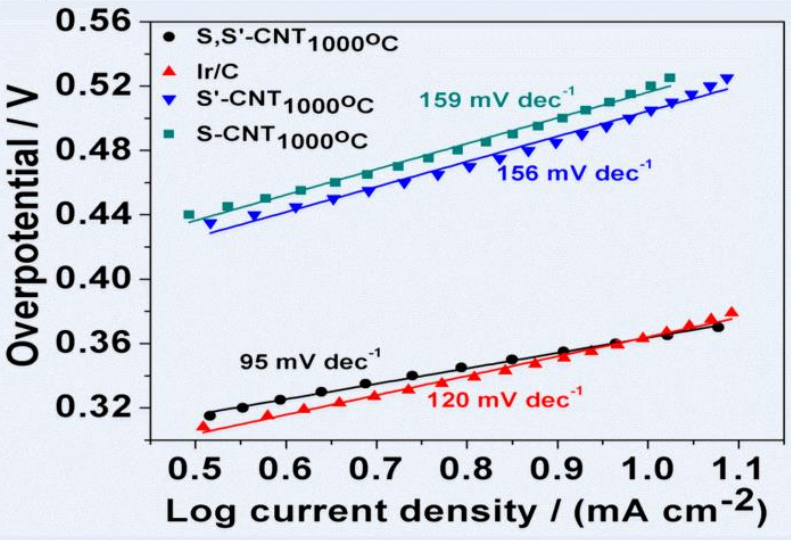

Figure 6. Oxygen evolution reaction activity (a) Linear sweep voltammetry (LSV) curves of the bi-doped $\mathrm{S}, \mathrm{S}^{\prime}-\mathrm{CNT}_{1000}{ }^{\circ} \mathrm{C}$ compared to $\mathrm{Ir} / \mathrm{C}$ in $1 \mathrm{M} \mathrm{KOH}$ at a scan rate of $5 \mathrm{mV} \mathrm{s}^{-1}$, and 1600 r.p.m. rotation speed (b) Comparison of LSV curves for various electrocatalysts at scan rate of $5 \mathrm{mV} \mathrm{s}^{-1}$ (c) Tafel plots of different S-doped CNT electrocatalysts vs. Ir/C. (d) Electrochemical impedance spectroscopy of different electrocatalysts at $1.68 \mathrm{~V}$ at a frequency region of $0.1-10^{5} \mathrm{~Hz}$. All CV, and LSV are iR compensated and the mass loading is $0.23 \mathrm{mg}$ 


\section{WILEY-VCH}

(a)

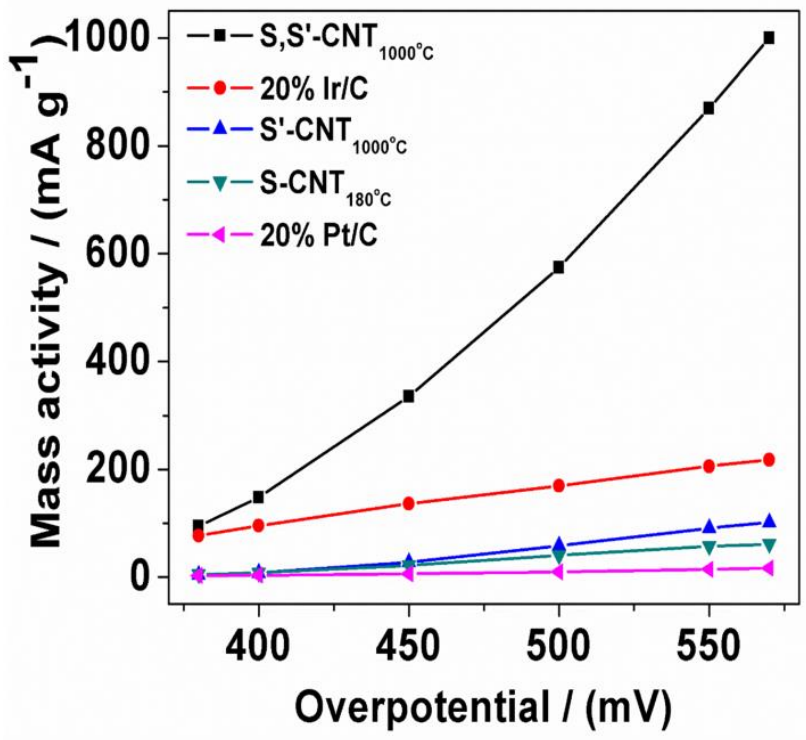

(b)

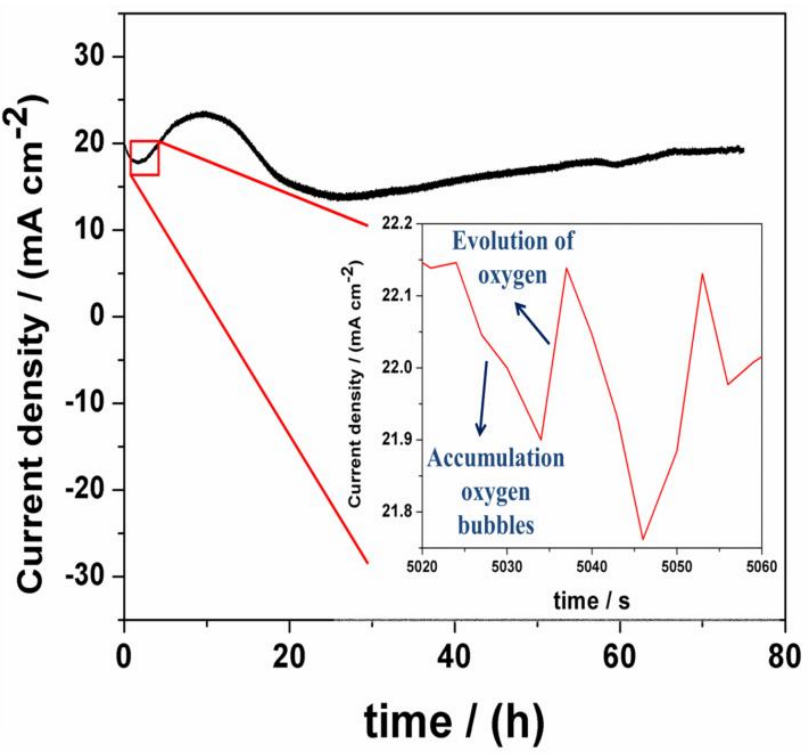

Figure 7. (a) Mass activity of sulfur doped carbon nanotubes compared to state-of-the-art catalysts. (b) Chronoamperometric study shows the stability test of S,S'-CNT $1000^{\circ} \mathrm{C}$ compared to $\mathrm{Ir} / \mathrm{C}$ and $\mathrm{S}-\mathrm{CNT}_{180^{\circ} \mathrm{C}}$. The bi-doping strategy retained $100 \%$ of its initial current density for 5.5h and has highest stability than the $\mathrm{Ir} / \mathrm{C}$ and $\mathrm{S}^{-} \mathrm{CNT}_{180^{\circ} \mathrm{C}}$, mass loading is $0.23 \mathrm{mg} \mathrm{cm}^{-2}$ at $\eta=400 \mathrm{mV}$.

Table 1. Oxygen evolution reaction parameters for active sulfur doped carbon nanotubegraphene nanolobes compared to state-of-the-art precious metal based catalysts.
$\eta(\mathrm{mV}) @$ Mass activity
TOF $\times 10^{-5}$
Tafel slope
$\mathrm{R}_{\mathrm{CT}} \quad \mathrm{k}^{\mathrm{0}} \times 10^{3}$
10
$\left(\mathrm{A} \mathrm{g}^{-1}\right)$
$\left(\mathrm{s}^{-1}\right) @$
$\left(\mathrm{mV} \mathrm{dec}{ }^{-1}\right)$
$(\Omega) \quad\left(\mathrm{cm} \mathrm{s}^{-1}\right)$
$\mathrm{mA} \mathrm{cm}{ }^{-2}$
@ $\eta=400 \mathrm{mV}$
$\eta=400 \mathrm{mV}$ 
WILEY-VCH

\begin{tabular}{rcccccc}
\hline S,S'-CNT $1000^{\circ} \mathrm{C}$ & 350 & 148 & 5.87 & 95 & 19 & 8.63 \\
$20 \%$ wt. Ir/C & 350 & 96 & 2.70 & 120 & 27 & 6.08 \\
S'-CNT $_{1000^{\circ} \mathrm{C}}$ & 490 & 8 & 0.93 & 156 & 47 & 3.49 \\
$20 \%$ wt. Pt/C & 710 & 4 & 0.11 & 334 & 1100 & 0.14 \\
\hline
\end{tabular}

\subsection{Oxygen reduction reaction}

The bi-doping strategy for sulfur on partially oxidized carbon nanotubes shows high catalytic activity not only for OER but also for ORR. The efficient bifunctionality shown by this material overcomes the major problems faced in development of regenerative fuel cells that require light weight active materials. The metal-free catalysts have very low mass density compared to state-of-the-art metals; the density of Ir is $22.52 \mathrm{~g} \mathrm{~cm}^{-3}$ for OER and Pt is $21.50 \mathrm{~g}$ $\mathrm{cm}^{-3}$ for ORR ${ }^{[29]}$ while the CNT is $1.3 \mathrm{~g} \mathrm{~cm}^{-3}$ which means that the mass density of CNT is less than these metals by a factor 16 .

To evaluate the oxygen reduction reaction activity of $\mathrm{S}, \mathrm{S}^{\prime}-\mathrm{CNT}_{1000^{\circ} \mathrm{C}}$ we ran cyclic voltammetry of $\mathrm{S}, \mathrm{S}^{\prime}-\mathrm{CNT}_{1000^{\circ} \mathrm{C}}$ which showed a cathodic reduction peak for ORR in oxygensaturated $1 \mathrm{M} \mathrm{KOH}$ centered at $780 \mathrm{mV}$ vs RHE, but in the absence of $\mathrm{O}_{2}$, the peak disappeared (Figure 8a). The activity of $\mathrm{S}, \mathrm{S}^{\prime}-\mathrm{CNT}_{1000^{\circ} \mathrm{C}}$ and other counterparts were compared to state-of-the-art 20\% Pt/C by using linear sweep voltammetry (LSV) (Figure $\mathbf{8 b}$ ). LSV shows that the cathodic reduction peak of $\mathrm{S}, \mathrm{S}^{\prime}-\mathrm{CNT}_{1000^{\circ} \mathrm{C}}$ shifted to a higher potential than the mono-doped sulfur CNTs. The reactivity of different sulfur carbon nanotube strategies was compared at $-3 \mathrm{~mA} \mathrm{~cm}^{-2}$ and the activity followed the trend $\mathrm{S}^{\prime}-\mathrm{CNT}_{1000^{\circ} \mathrm{C}}<\mathrm{S}-$

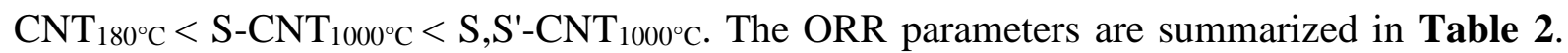
Though the $\mathrm{S}, \mathrm{S}^{\prime}-\mathrm{CNT}_{1000^{\circ} \mathrm{C}}$ is negatively shifted from $20 \% \mathrm{Pt} / \mathrm{C}$ by only $40 \mathrm{mV}$, the TOF at $750 \mathrm{mV}$ is nearly twice that of $\mathrm{Pt} / \mathrm{C}$. This activity was further confirmed by comparing the Tafel slopes of $\mathrm{S}, \mathrm{S}^{\prime}-\mathrm{CNT} 1000^{\circ} \mathrm{C}(46.0 \mathrm{mV}$ per decade) with those of the Pt/C catalyst $(57.6 \mathrm{mV}$ 


\section{WILEY-VCH}

per decade) and also against counterparts (Figure 8c). The linearity of Figure 8c suggests that the sulfur doped carbon nanotubes follow the same mechanism and the first electron transfer may be the rate-determining step. ${ }^{[30],[23]}$

The outstanding ORR activity of $\mathrm{S}, \mathrm{S}^{\prime}-\mathrm{CNT}_{1000^{\circ} \mathrm{C}}$ over other different doping strategies was confirmed by electrochemical impedance spectroscopy at $0.65 \mathrm{~V}$ in the frequency region of $0.1-10^{5} \mathrm{~Hz}$ (Figure 8d). The $\mathrm{S}, \mathrm{S}^{\prime}-\mathrm{CNT}_{1000^{\circ} \mathrm{C}}$ has the lowest charge transfer resistance $\left(\mathrm{R}_{\mathrm{CT}}\right)$ and highest standard rate constant which followed the order of the activity trend. KouteckyLevich (K-L) plots (Figure 8f) derived from polarization of $\mathrm{S}, \mathrm{S}^{\prime}-\mathrm{CNT}_{1000^{\circ} \mathrm{C}}$ at different rotation speeds (400-2400 r.p.m.) showed good linearity (Figure 8e) which indicates first order reaction kinetics with respect to oxygen. ${ }^{[30]}$ The K-L equation of the $\mathrm{S}, \mathrm{S}^{\prime}-\mathrm{CNT}_{1000^{\circ} \mathrm{C}}$ have an average of 4 electrons transferred over a range of potentials from 0.6 to $0.8 \mathrm{~V}$. In order to assess the stability, chronoamperometry studies of $\mathrm{S}, \mathrm{S}^{\prime}-\mathrm{CNT}_{1000^{\circ} \mathrm{C}}$ and $20 \% \mathrm{Pt} / \mathrm{C}$ were carried out at $0.4 \mathrm{~V}$ at rotation speeds of 1600 r.p.m (Figure S17). Pt/C lost $~ 22 \%$ from its initial activity within the first 25 min of operation, as compared to $\mathrm{S}, \mathrm{S}^{\prime}-\mathrm{CNT}_{1000^{\circ} \mathrm{C}}$ whose activity decreased only $2.3 \%$ under the same conditions. Under long-term operation, $\mathrm{S}, \mathrm{S}^{\prime}-\mathrm{CNT}_{1000^{\circ} \mathrm{C}}$ showed good stability for 8 hours and retained about $71.6 \%$ of its original current density, but $\mathrm{Pt} / \mathrm{C}$ retained only $65.1 \%$ at 5 hours.

The S,S'-CNT $1000^{\circ} \mathrm{C}$ showed strong chemical resistance under alcohol conditions. This is important for the transporting across membranes of fuel cells. The current density did not change by introducing methanol to the reaction, while the current density of $\mathrm{Pt} / \mathrm{C}$ increased due to oxidation of methanol (Figure S18). ${ }^{[16 a-e]}$ This $\mathrm{S}, \mathrm{S}^{\prime}-\mathrm{CNT}_{1000^{\circ} \mathrm{C}}$ system is a potential cathode candidate catalyst not only for alkaline and regenerative fuel cells but also for directmethanol fuel cells. 
WILEY-VCH

(a)

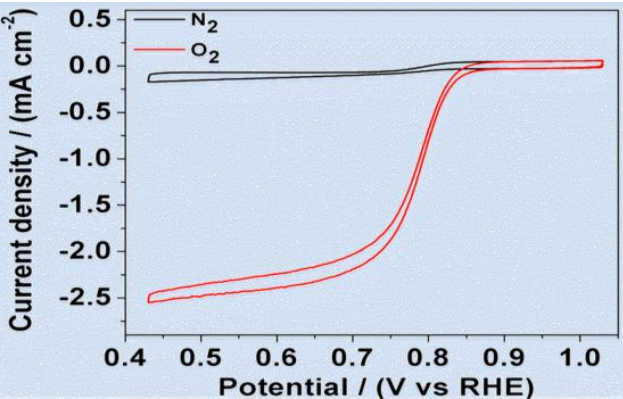

(c)

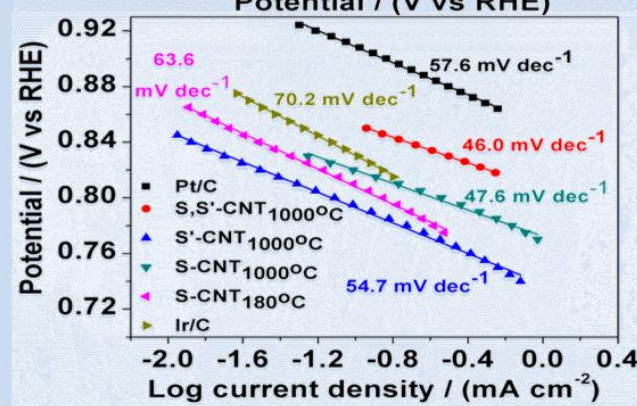

(e)

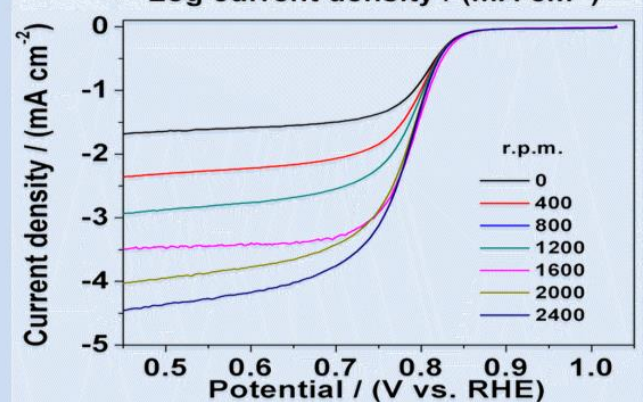

(b)

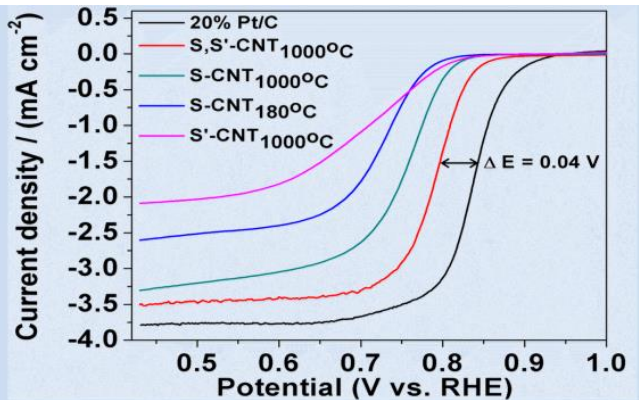

(d)

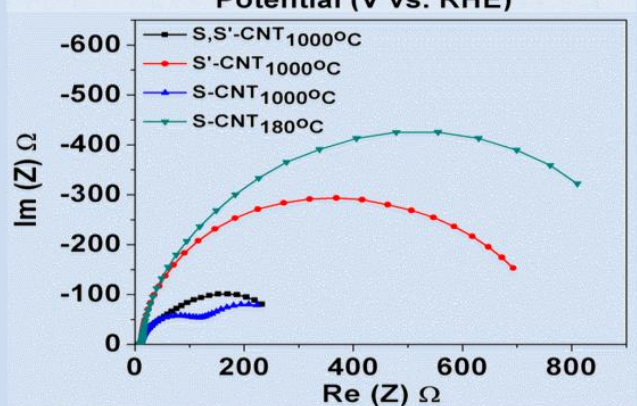

(f)

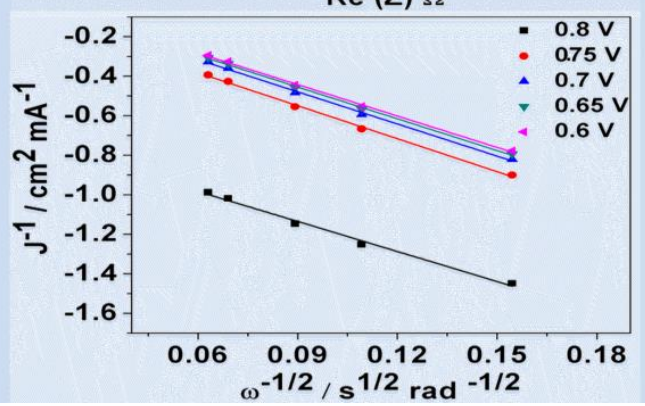

Figure 8. Oxygen reduction reaction activity (a) Cyclic voltammogram of $\mathrm{S}, \mathrm{S}^{\prime}-\mathrm{CNT} 1000^{\circ} \mathrm{C}$ in $\mathrm{O}_{2}$ and $\mathrm{N}_{2}$ atmospheres (b) linear sweep voltammogram for ORR activity of $\mathrm{Pt} / \mathrm{C}$ and different sulfur doped CNTs (c) Tafel plot of Pt/C and different sulfur doped CNTs (d) EIS for different sulfur doped CNTs at $0.78 \mathrm{~V}$ at a frequency region of $0.1-10^{5} \mathrm{~Hz}$ (e) linear sweep voltammogram of $\mathrm{S}, \mathrm{S}^{\prime}-\mathrm{CNT}_{1000^{\circ} \mathrm{C}}$ at different rotation speeds (400-2400 r.p.m.) (f) K-L plots for $\mathrm{S}, \mathrm{S}^{\prime}-\mathrm{CNT}_{1000^{\circ} \mathrm{C}}$ at different potentials. All CVs and LSVs were done in $1 \mathrm{M} \mathrm{KOH}$, at a scan rate of $5 \mathrm{mV} \mathrm{s}^{-1}$, mass loading of $0.23 \mathrm{mg} \mathrm{cm}^{-2}$ for all catalysts and all $\mathrm{CV}$, and LSV are iR compensated. 


\section{WILEY-VCH}

Table 2. Oxygen reduction reaction parameters for active sulfur doped carbon nanotubegraphene nanolobes compared to state-of-the-art catalysts

\begin{tabular}{|c|c|c|c|c|c|}
\hline & $\mathrm{E}_{0}(\mathrm{~V})$ & $\mathrm{E}_{1 / 2}(\mathrm{~V})$ & E (V) @ & TOF $\times 10^{-6}\left(\mathrm{~s}^{-1}\right)$ & Tafel slope \\
\hline & & & $-3 \mathrm{~mA} \mathrm{~cm}{ }^{-2}$ & @ $750 \mathrm{mV}$ & $\left(\mathrm{mV} \mathrm{dec}{ }^{-1}\right)$ \\
\hline $\mathrm{S}, \mathrm{S}^{\prime}-\mathrm{CNT}_{1000^{\circ} \mathrm{C}}$ & 0.87 & 0.79 & 0.74 & 5.8 & 46.0 \\
\hline $20 \%$ wt. Ir/C & 0.83 & 0.63 & 0.61 & 0.9 & 70.2 \\
\hline $\mathrm{S}^{\prime}-\mathrm{CNT} 1000^{\circ} \mathrm{C}$ & 0.80 & 0.72 & N/A & 4.2 & 54.7 \\
\hline $20 \%$ wt. $\mathrm{Pt} / \mathrm{C}$ & 0.93 & 0.83 & 0.80 & 5.8 & 57.6 \\
\hline
\end{tabular}

\section{Discussion}

We have developed a novel bi-doping strategy to control the active sites of sulfur doped carbon nanotubes at the atomic-scale. This leads to a boost in the activity of the oxygen evolution reaction (OER) and $\mathrm{S}, \mathrm{S}-\mathrm{CNT}_{1000^{\circ} \mathrm{C}}$ is shown to be the most active and stable metalfree OER catalyst known to date (Table S4). We show for the first time how to tune active sites by changing the doping precursors which, in turn, control the electrochemical activity. Besides the outstanding performance and durability of sulfur bi-doped carbon nanotubes, these materials have other significant features such as low cost, and low mass density relative to state-of-the-art systems generating a potential candidate for the light-weight regenerative fuel cells. ${ }^{[16 a]}$

Advanced characterization techniques have been used to identify and correlate the various sulfur active sites with electrocatalytic activity. These techniques revealed that the activity was boosted by lowering the oxygen content which enhances conductivity and electron mobility. XANES analyses suggested that the most active catalyst is the one which has the highest content of heterocyclic sulfur. High resolution imaging (HRTEM, HAADFSTEM, EELS mapping and spectra) confirm that the sulfur hetero atoms have a uniform 


\section{WILEY-VCH}

distribution on the CNT and nanolobes representing partially unzipped CNT which make these active sites more accessible to the reaction medium.

Integration of material characterization results, electrochemical activity measurements, stability trends and comparison with other reported OER mechanisms, ${ }^{[31]}$ and theoretical studies $^{[32]}$ suggest a proposed mechanism for OER over the sulfur bi-doped carbon nanotubes. As shown in Figure 9, sulfur incorporated into the carbon $\mathrm{sp}^{2}$ network of the nanotubes facilitates peroxide formation leading to oxygen evolution.

The metal content of CNTs detected by ICP-MS is trace amounts of Co $\left(1.16 \times 10^{-6} \mathrm{~g}\right.$ of Co per $1 \mathrm{~g}$ of CNT). These trace impurities of Co cannot be detected by XPS and SEMEDX. The trace element doping of Co and the CNT and CNT pyrolyzed at $1000^{\circ} \mathrm{C}$ have poor catalytic activity. This suggested that the trace amount of Co on the CNT during its growth did not contribute in the OER activity. The role of oxygen and defects on the CNT are

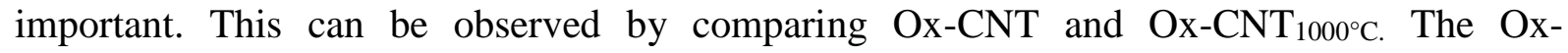

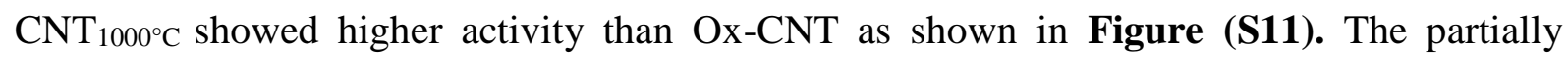
oxidized carbon nanotube has high content of oxygen defects that hinder the electron transport in the carbon nanotubes by decreasing the conductivity. Upon removing the oxygen by pyrolysis at $1000^{\circ} \mathrm{C}$ and restoring the conductivity of CNT, the OER activity is enhanced due only to structure defects formed by oxidation of CNTs. Increasing the CNT defects leads to OER enhancement. The OER activity of the doped carbon nanotubes is in the order S,S'-

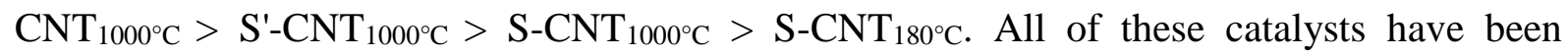
treated with the same reagent CNT, BDS, and thiourea, but under different conditions. This completely eliminates any metal activity and the only factor affecting the activity is the nature of active sites (C-S-C). The Ox-CNT treated with thiourea under hydrothermal treatment to form S-CNT $180^{\circ} \mathrm{C}$ this catalyst showed poor catalytic activity even though this material has the highest amount of sulfur and oxygen suggesting that hydrothermal treatment is not enough to restore the conductivity of the CNTs. 


\section{WILEY-VCH}

The low binding energy of sulfur was confirmed by removing these sulfur atoms upon

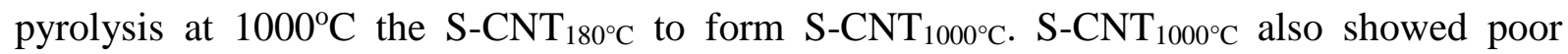
catalytic activity due to the absence of any active sites (C-S-C). Stabilizing the sulfur occurs

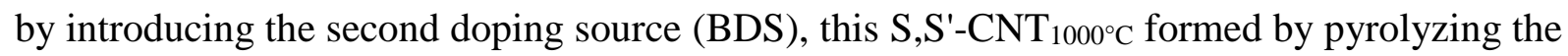
$\mathrm{S}-\mathrm{CNT}_{180^{\circ} \mathrm{C}}$ in the presence of BDS. This leads to stable active sites (C-S-C) and an increase in the defects of CNT by formation of a complex structure of graphene nanolobes attached to the walls of CNTs. This leads to enhancement of the OER activity of S,S'-CNT $1000^{\circ} \mathrm{C}$. In order to investigate the BDS doping, single doping of Ox-CNT with BDS by pyrolysis was used to form $\mathrm{S}^{\prime}-\mathrm{CNT}_{1000^{\circ} \mathrm{C} .} \mathrm{S}^{\prime}-\mathrm{CNT}_{1000^{\circ} \mathrm{C}}$ has a higher activity than other monodoped catalysts because due to a higher amount of stable active sites.

The OER reaction, catalyzed by $\mathrm{S}, \mathrm{S}^{\prime}-\mathrm{CNT}_{1000^{\circ} \mathrm{C}}$ begins by addition of two hydroxides $\left(\mathrm{OH}^{-}\right)$to the adjacent sulfur's carbon atoms on the thiophene ring (step 1), followed by addition of another $2 \mathrm{OH}^{-}$to form an intermediate structure (step 2). This intermediate structure undergoes rearrangement by removal of two molecules of water and four electrons to form two oxygen radicals bonded to carbon (step 3). Step 4 involves the formation of a peroxide bond (O-O). Finally, the oxygen molecule is evolved in step 5. On the basis of that

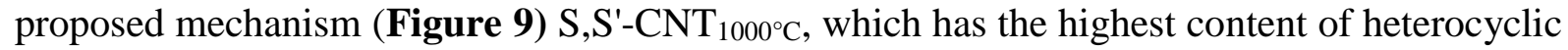
sulfur of the studied materials, is the most active and stable catalyst. The bifunctionality of $\mathrm{S}, \mathrm{S}^{\prime}-\mathrm{CNT}_{1000^{\circ} \mathrm{C}}$ showed the superior performance as compared to noble metal catalysts as well as other active metal oxide systems (Table 3). ${ }^{[31,33]}$ The bi-doped sulfur carbon nanotube has outstanding stability and durability at high current density $\left(10 \mathrm{~mA} \mathrm{~cm}^{-2}\right)$. The current density increased during the stability tests to $120 \%$ from its initial current density which is considered as self-healing. A few materials have been reported to have the same activation behavior such as $\alpha-\mathrm{Ni}(\mathrm{OH})_{2}{ }^{[34]}$ and $\mathrm{MnO}_{\mathrm{x}}{ }^{[35]}$. During polarization of $\mathrm{S}, \mathrm{S}^{\prime}-\mathrm{CNT}_{1000^{\circ} \mathrm{C}}$ in the OER, the oxygen evolution from the electrode surface led to rearrangement of the active material to increase the accessibility of electrolyte to the sulfur active sites. 


\section{WILEY-VCH}

Ex-situ Raman (Figure S19) and SEM (Figure S20) for $\mathrm{S}, \mathrm{S}^{\prime}-\mathrm{CNT}_{1000} \mathrm{C}^{\mathrm{C}}$ under $\mathrm{OER}$ conditions at different time intervals showed that the ratio of the $\mathrm{I}_{\mathrm{D}}: \mathrm{I}_{\mathrm{G}}$ increased after $5 \mathrm{~h}$ of OER operation due to increasing the disorder of CNT by introducing surface functionalizing groups on the carbon bound to sulfur atoms of CNT. This explains the increase in the activity under OER conditions. The SEM images showed that the Nafion, which is used as a binder, leads to aggregation of the CNTs on the pyrolytic graphite electrode. After $5 \mathrm{~h}$ and 2 days of OER operations, there is no obvious damage to the CNT but after 3 days the CNT starts to decompose as shown in time-dependent studies (Figure S20).

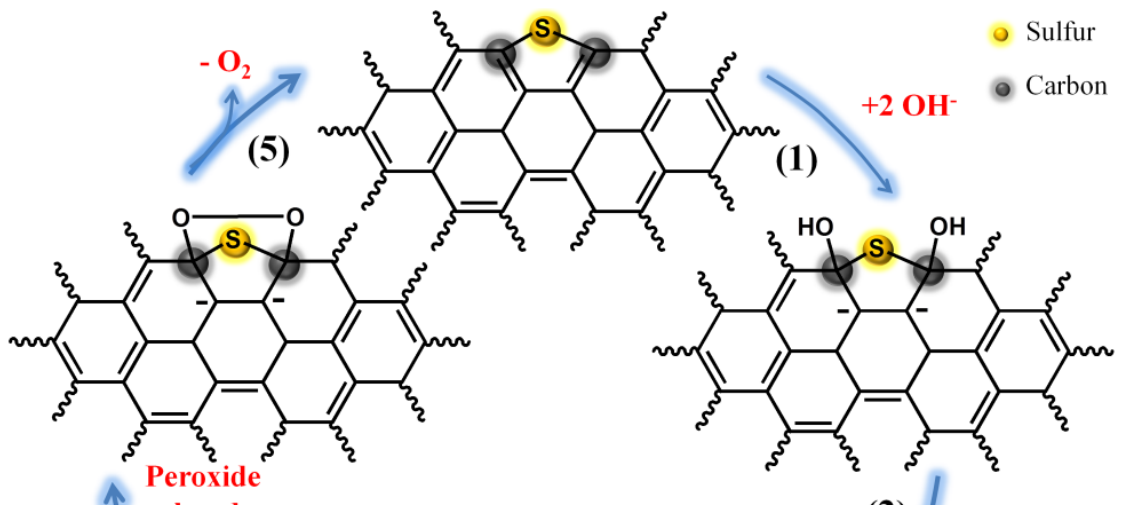

(4)

(2)

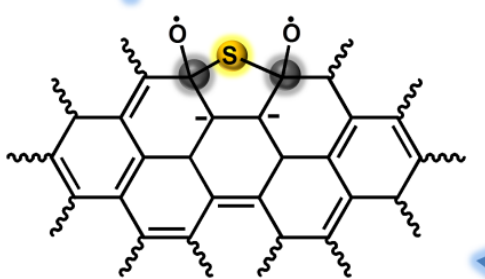

(3)

$-2 \mathrm{H}_{2} \mathrm{O},-4 \mathrm{e}^{-}$

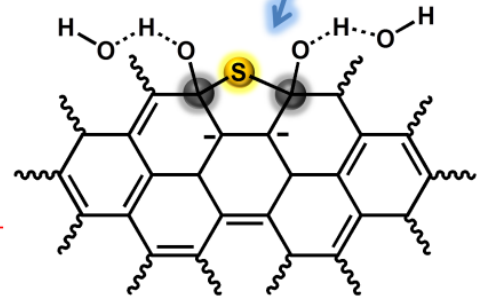

Figure 9. Proposed mechanism for oxygen evolution reaction of sulfur doped carbon nanotubes. The mechanism involves the addition of $4 \mathrm{OH}^{-}$and the formation of peroxide bond to facilitate the oxygen evolution.

Table 3. The bifunctionality assessment of $\mathrm{S}, \mathrm{S}^{\prime}-\mathrm{CNT} 1000^{\circ} \mathrm{C}$ compared to state-of-the-art catalysts
$\operatorname{EOER}(\mathrm{V}) @$
EORR (V)@
$\Delta \mathrm{E}(\mathrm{V})$
$10 \mathrm{~mA} \mathrm{~cm}^{-2} \quad-3 \mathrm{~mA} \mathrm{~cm}^{-2}$
(EOER - EORR)

\begin{tabular}{llll}
$\mathrm{S}, \mathrm{S}^{\prime}-\mathrm{CNT}_{1000^{\circ} \mathrm{C}}$ & 1.58 & 0.74 & 0.84 \\
\hline
\end{tabular}




$\begin{array}{llll}20 \% \text { wt. } \mathrm{Ir} / \mathrm{C} & 1.58 & 0.61 & 0.97\end{array}$

20\% wt. Pt/C $\quad 1.94 \quad 0.80 \quad 1.14$

\section{Conclusion}

We have developed a novel strategy to tune and stabilize the active sites of metal-free CNTbased catalysts. A new sequential bi-doping strategy was used to control the nature of sulfur active sites for sulfur doped carbon nanotube-graphene nanolobe materials. This leads to enhanced catalytic activity of bi-doped carbon nanotubes, resulting in one of the most active catalysts for the oxygen evolution reaction. This system also functions with the lowest observed overpotential, $350 \mathrm{mV}$ at $10 \mathrm{~mA} \mathrm{~cm}$, reported for metal-free catalysis until now and performs like the state-of-the-art catalyst (20\% Ir/C) but with a much higher (10 times) turnover frequency. In addition to outstanding catalytic activity for OER, the bi-doped catalyst exhibited very high stability for periods up to $5.5 \mathrm{~h}$. HR-TEM and STEM-HAADF techniques reveal the unique attachment of graphene nanolobes to the walls of CNT also the uniform distribution of sulfur on the CNT. XANES and XPS helped explain the outstanding activity and stability by showing high amounts of sulfur incorporated inside the rings of carbon nanotubes of the bi-doped CNT. The same behavior extends to the oxygen reduction reaction where the bi-doped sulfur catalyst has high catalytic activity comparable to that of $20 \% \mathrm{Pt} / \mathrm{C}$. The bifunctionality of the bi-doped sulfur catalyst stands to currently be the most active bifunctional metal-free catalyst, which makes this material a potential candidate for next-generation metal-free regenerative fuel cells. This sequential two-step doping strategy can be used to control the active sites of other heteroatoms (N, P, and B, etc) in the skeleton of any carbon sources (CNT, graphene, etc.) that will open a new avenue for more efficient electrochemical reactions (hydrogen evolution, and carbon dioxide reduction reactions, etc.) of metal-free catalysts.

\section{Experimental section}




\section{WILEY-VCH}

\section{List of chemicals}

97\% Multiwalled carbon nanotubes (Catalog \# 724769-25G), 99\% potassium permanganate, $35 \%$ hydrogen peroxide, $90 \%$ potassium hydroxide, $95 \%$ dibenzyl sulfide, $99 \%$ thiourea, $20 \%$ Nafion, $99.9 \%$ iridium trichloride hydrate, $20 \% \mathrm{Pt} / \mathrm{C}$, sulfuric acid, hydrochloric acid were purchased from Sigma Aldrich. Absolute ethanol was obtained from Pharmco-Aaper. Carbon black was purchased from Cabot Corporation. All chemicals were used as received without any further purification.

\section{Synthesis of sulfur doped carbon nanotubes}

Partially unzipped CNT (Ox-CNT) was prepared by the same procedure of previously reported Kosynkin, D.V. et al. ${ }^{[22]}$ with little modification. CNT $(1 \mathrm{~g})$ were suspended in concentrated $\mathrm{H}_{2} \mathrm{SO}_{4}(300 \mathrm{~mL})$ for $1 \mathrm{~h}$ at room temperature, then followed by slow addition of $\mathrm{KMnO}_{4}(5 \mathrm{~g})$, and the mixture was allowed to stir for $1 \mathrm{~h}$ at room temperature. The reaction was then heated in an oil bath at $55{ }^{\circ} \mathrm{C}$ for $30 \mathrm{~min}$, then raised to $70{ }^{\circ} \mathrm{C}$ for another $30 \mathrm{~min}$. Then reaction was allowed to cool to room temperature under continuous stirring. The reaction was quenched by pouring the reaction mixture over an ice bath containing $20 \mathrm{~mL}$ of $30 \% \mathrm{H}_{2} \mathrm{O}_{2}$. The product was collected by centrifuge at 7500 r.p.m., washed several times with $\mathrm{HCl}$, then DI water and finally with ethanol. The sample was dried under vacuum at 60 ${ }^{\circ} \mathrm{C}$ overnight.

Firstly, doping of sulfur was done by sonication of Ox-CNT $(300 \mathrm{mg})$ in $30 \mathrm{~mL}$ double deionized water, and then thiourea ( $3 \mathrm{~g}$ ) was added into the solution with stirring. The suspended solution was transferred into Teflon-lined stainless steel autoclave, and the temperature was maintained at $180{ }^{\circ} \mathrm{C}$ for $8 \mathrm{~h}$. The reaction mixture was cooled to room temperature, washed repeatedly in water, and dried under vacuum at $60{ }^{\circ} \mathrm{C}$. The obtained sulfur doped CNT abbreviated as $\mathrm{S}-\mathrm{CNT}_{180^{\circ}} \mathrm{C}$. The second doping of sulfur $\left(\mathrm{S}, \mathrm{S}^{\prime}-\mathrm{CNT}_{1000^{\circ} \mathrm{C}}\right)$

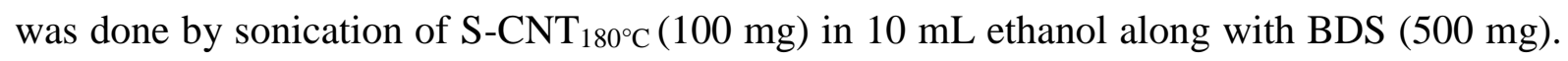
The solution was allowed to dry under ambient conditions. The obtained solids were loaded 


\section{WILEY-VCH}

in quartz tube and pyrolyzed under $\mathrm{N}_{2}$ at $1000{ }^{\circ} \mathrm{C}$ for $1 \mathrm{~h}$ with ramping rate $10{ }^{\circ} \mathrm{C} \mathrm{min}{ }^{-1}$. S-

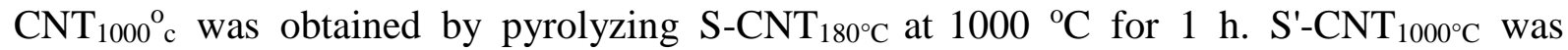
obtained by using the same conditions of synthesis $\mathrm{S}, \mathrm{S}^{\prime}-\mathrm{CNT} 1000^{\circ} \mathrm{C}$ but the starting precursor was Ox-CNT.

Synthesis of $20 \%$ Ir/C catalyst

Synthesis was done by simple incipient wetness impregnation method. ${ }^{[33 \mathrm{~b}]} \mathrm{IrCl}_{3} \cdot \mathrm{xH}_{2} \mathrm{O}$ $(0.155 \mathrm{~g})$ was dissolved in $1.5 \mathrm{~mL}$ of acetone, followed by the addition of $0.5 \mathrm{~g}$ of carbon black. The mixture was left dry at room temperature for $2 \mathrm{~h}$ then overnight at $60{ }^{\circ} \mathrm{C}$. The composite was heated for $2 \mathrm{~h}$ at $400{ }^{\circ} \mathrm{C}$ under $\mathrm{H}_{2}$ flow.

\section{Electrochemical measurement}

Electrode inks were prepared by dispersing the active materials $(4 \mathrm{mg})$ in a mixture of ethanol $(200 \mu \mathrm{L})$ and water $(800 \mu \mathrm{l})$, then $85 \mu \mathrm{L}$ of Nafion (35\%) was added. The mixture was sonicated for $30 \mathrm{~min}$. About $10 \mu \mathrm{L}$ of the ink was allowed to dry overnight at room temperature on $0.13 \mathrm{~cm}^{2}$ of pyrolytic graphite electrode as the working electrode. A CHI potentiostat workstation with a standard 3-electrode setup where a pyrolytic graphite rod electrode was used as counter electrode, and saturated calomel electrode was used for a reference electrode in $1 \mathrm{M} \mathrm{KOH}$ for electrolyte. The overpotential $(\eta)=($ equilibrium potential of oxygen evolution reaction $\left(E_{\mathrm{O}_{2} / \mathrm{H}_{2} \mathrm{O}}=1.23\right)$ - applied potential of RHE). Cyclic voltammetry $(\mathrm{CV})$ and linear sweep voltammetry (LSV) were conducted at scan rate $5 \mathrm{mV} / \mathrm{s}$

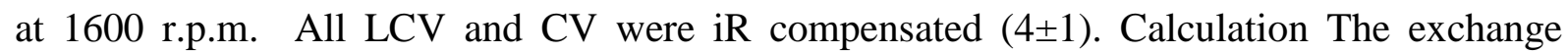
current density $\left(\mathrm{mA} \mathrm{cm}{ }^{-2}\right)\left(\mathrm{J}_{\mathrm{O}}\right)=\frac{R T}{n F A R_{C T}} ; \mathrm{R}$ is the gas constant $8.31 \mathrm{~J} \mathrm{~mol}^{-1} \mathrm{~K}^{-1}, \mathrm{~T}$ is the absolute temperature $298^{\circ} \mathrm{K}, \mathrm{n}$ is the number of electron transfer 4 . $\mathrm{F}$ is the Faraday's constant (96485.3 $\mathrm{C} \mathrm{mol}^{-1}$ ), $\mathrm{A}$ is the geometrical electrode surface area, $\mathrm{R}_{\mathrm{CT}}$ is the charge transfer resistance. The standard rate constant $\left(\mathrm{k}^{\circ}\right)\left(\mathrm{cm} \mathrm{s}^{-1}\right)=\frac{J_{o}}{n F C_{O_{2}}} ; C_{O_{2}}$ is the saturated concentration of oxygen in $1 \mathrm{M} \mathrm{KOH}\left(7.8 \times 10^{-7} \mathrm{~mol} \mathrm{~cm}^{-3}\right)$. Calculation of mass activity was done by the 


\section{WILEY-VCH}

formula $\left(\mathrm{A} \mathrm{g}^{-1}\right)=\frac{\mathrm{J}}{\mathrm{m}} ; \mathrm{J}$ is the current density $\left(\mathrm{mA} \mathrm{cm}^{-2}\right)$ at $\eta=400 \mathrm{mV}$, and $\mathrm{m}$ is the mass loading of electroactive materials $\left(0.23 \mathrm{mg} \mathrm{cm}^{-2}\right.$ geo $)$. Turnover frequency $(\mathrm{TOF})\left(\mathrm{s}^{-1}\right)=\frac{\mathrm{JA}}{4 \mathrm{n} \mathrm{F}}$ with $\mathrm{J}$ as the current density $\left(\mathrm{A} \mathrm{cm}^{-2}\right)$ at $\eta=400 \mathrm{mV}$ and $\mathrm{n}$ is the moles of the active atoms on the electrode calculated from $\mathrm{m}$ and the atomic weight of the catalysts (more details is in supporting information) Rotating disk electrode measurements (RDE) were carried out the same way as LSV but the working electrode was rotated from 400 to 2400 r.p.m. KouteckyLevich plots $\left(\mathrm{J}^{-1}\right.$ vs $\left.\omega^{-1 / 2}\right)$ were used to determine the number of electrons transferred at different potentials from their slopes of the best linear fit on the basis of the Koutecky-Levich (K-L) equation $\frac{1}{J}=\frac{1}{J_{L}}+\frac{1}{J_{K}}=\frac{1}{B \omega^{0.5}}+\frac{1}{J_{K}}, B=0.62 n F C_{o} D_{o}^{2 / 3} v^{-1 / 6}$, where $\mathrm{J}$ is the measured current density, $\mathrm{J}_{\mathrm{L}}$ and $\mathrm{J}_{\mathrm{K}}$ are the limiting and kinetic diffusion-limiting current densities, respectively, $\mathrm{B}$ is the reciprocal of the slope, $\omega$ is the angular velocity of the electrode $\left(\mathrm{rad} . \mathrm{s}^{-1}\right), \mathrm{n}$ is the number of electrons transferred, $\mathrm{F}$ is the Faraday constant. $\mathrm{C}_{\mathrm{o}}$ is the saturated concentration of oxygen in $1 \mathrm{M} \mathrm{KOH}\left(7.8 \times 10^{-7} \mathrm{~mol} \mathrm{~cm}^{-3}\right), \mathrm{D}_{\mathrm{o}}$ is the oxygen diffusion coefficient $\left(1.43 \times 10^{-5} \mathrm{~cm}^{2} \mathrm{~s}^{-1}\right)$, and $v$ is the kinetic viscosity of electrolyte $(0.01$ $\left.\mathrm{cm}^{2} \mathrm{~s}^{-1}\right)$

\section{Material characterization}

The morphology of synthesis materials was investigated by using an FEI Nova NanoSEM 450 field emission scanning electron microscopy (FE-SEM). Energy dispersive spectroscopy (EDS) was collected with an X-Max 80 silicon drift detector. High-resolution transmission electron microscopy (HRTEM) was done by a JEOL 2010 instrument with an accelerating voltage of 200. HADF-STEM and EELS analyses were obtained on a Hitachi HD2700C (200 kV) with a Cs-aberration-correction equipped cold field emission electron gun (FEG) and a high-resolution parallel EELS detector (Gatan Enfina-ER) at the Center for Functional Nanomaterial (CFN) at Brookhaven National Laboratory (BNL). X-ray photoelectron spectroscopy (XPS) was performed on a PHI model 590 spectrometer with 


\section{WILEY-VCH}

(Physical Electronics Industries Inc.) using $\mathrm{Al} \mathrm{K \alpha}$ radiation $(\lambda=1486.6 \mathrm{eV})$ as the radiation source. The powder samples were pressed on carbon tape and mounted on adhesive copper tape. Survey scans were taken at pass energy of $200 \mathrm{eV}$ and the high resolution scans at 50 $\mathrm{eV}$. The $\mathrm{C} 1 \mathrm{~s}$ peak position was set to $284.5 \mathrm{eV}$ as an internal standard. Sulfur K-edge X-Ray Absorption Spectroscopy (XAS) measurements were done in fluorescence mode at beamline X19A of National Synchrotron Light Source (NSLS) at BNL. The beamline was calibrated by using the native sulfur K-edge at $2472.00 \mathrm{eV}$. ATHENA software package was used to process the X-Ray absorption near edge spectroscopy (XANES) data. The Raman spectra were taken on a Renishaw 2000 Raman microscope at $532 \mathrm{~nm}$ excitation.

\section{Supporting Information}

Supporting Information is available from the Wiley Online Library.

\section{Acknowledgment}

We thank the Department of Energy, Office of Basic Energy Sciences, Division of Chemical, Geological and Biological Sciences under grant DE-FGO2-86ER13622.A000 for support of this work. We gratefully acknowledge the assistance of the Bioscience Electron Microscopy Laboratory of the University of Connecticut and grant \# 1126100 for the purchase of the FEI NovaSEM. A.M.E., and I.M.S. thank the Ministry of Higher Education in Egypt for financial support.

[1] R. Subbaraman, D. Tripkovic, K. C. Chang, D. Strmcnik, A. P. Paulikas, P. Hirunsit, M. Chan, J. Greeley, V. Stamenkovic, N. M. Markovic, Nat. Mater. 2012, 11, 550-557.

[2] M. Carmo, D. L. Fritz, J. Merge, D. Stolten, Int. J. Hydrogen Energ. 2013, 38, 4901-4934.

[3] J. Suntivich, K. J. May, H. A. Gasteiger, J. B. Goodenough, Y. Shao-Horn, Science 2011, 334, 1383-1385.

[4] T. W. Kim, K. S. Choi, Science 2014, 343, 990-994.

[5] M. J. Kenney, M. Gong, Y. G. Li, J. Z. Wu, J. Feng, M. Lanza, H. J. Dai, Science 2013, 342, 836840.

[6] Q. S. Yin, J. M. Tan, C. Besson, Y. V. Geletii, D. G. Musaev, A. E. Kuznetsov, Z. Luo, K. I. Hardcastle, C. L. Hill, Science 2010, 328, 342-345.

[7] A. Grimaud, K. J. May, C. E. Carlton, Y. L. Lee, M. Risch, W. T. Hong, J. G. Zhou, Y. Shao-Horn, Nat. Commun. 2013, 4, 2439. 


\section{WILEY-VCH}

[8] A. J. Esswein, M. J. McMurdo, P. N. Ross, A. T. Bell, T. D. Tilley, J. Phys. Chem. C 2009, 113, 15068-15072.

[9] T. Maiyalagan, K. A. Jarvis, S. Therese, P. J. Ferreira, A. Manthiram, Nat. Commun. 2014, 5, 3949.

[10] X. Liu, Z. Chang, L. Luo, T. Xu, X. Lei, J. Liu, X. Sun, Chem. Mater. 2014, 26, , 1889-1895.

[11] A. Iyer, J. Del-Pilar, C. K. King'ondu, E. Kissel, H. F. Garces, H. Huang, A. M. El-Sawy, P. K. Dutta, S. L. Suib, J. Phys. Chem. C 2012, 116, 6474-6483.

[12] R. Pokhrel, M. K. Goetz, S. E. Shaner, X. Wu, S. S. Stahl, J. Am. Chem. Soc.2015, 137, 83848387.

[13] A. M. El-Sawy, C. K. King'ondu, C. Kuo, D. A. Kriz, C. J. Guild, C. Meng, S. J. Frueh, S. Dharmarathna, S. N. Ehrlich, S. L. Suib, Chem. Mater. 2014, 26, 5752-5760.

[14] a) Y. Gorlin, C. J. Chung, J. D. Benck, D. Nordlund, L. Seitz, T. C. Weng, D. Sokaras, B. M. Clemens, T. F. Jaramillo, J. Am. Chem. Soc. 2014, 136, 4920-4926; b) C. H. Kuo, W. Li, L. Pahalagedara, A. M. El-Sawy, D. Kriz, N. Genz, C. Guild, T. Ressler, S. L. Suib, J. He, Angew. Chem. Int. Ed. 2015, 54, 2345-2350.

[15] Z. Zhuang, W. Sheng, Y. Yan, Adv. Mater. 2014, 26, 3950-3955.

[16] a) K. P. Gong, F. Du, Z. H. Xia, M. Durstock, L. M. Dai, Science 2009, 323, 760-764; b) J. Liang, Y. Jiao, M. Jaroniec, S. Z. Qiao, Angew. Chem. Int. Ed. 2012, 51, 11496-11500; c) Z. Yang, Z. Yao, G. F. Li, G. Y. Fang, H. G. Nie, Z. Liu, X. M. Zhou, X. Chen, S. M. Huang, ACS Nano 2012, 6, 205-211; d) C. Z. Zhang, N. Mahmood, H. Yin, F. Liu, Y. L. Hou, Adv. Mater. 2013, 25, 49324937; e) Y. Zheng, Y. Jiao, L. Ge, M. Jaroniec, S. Z. Qiao, Angew. Chem. Int. Ed. 2013, 52, 31103116; f) J. Tang, J. Liu, C. Li, Y. Li, M. O. Tade, S. Dai, Y. Yamauchi, Angew. Chem. Int. Ed. 2015, 54, 588-593; g) Z. Lin , G. Waller , Y. Liu , M. Liu , C. P. Wong, Adv. Energy Mater. 2012, 2, 884-888.

[17] Y. Zheng, Y. Jiao, L. H. Li, T. Xing, Y. Chen, M. Jaroniec, S. Z. Qiao, ACS nano 2014, 8, 52905296.

[18] a) S. Chen, J. Duan, M. Jaroniec, S. Z. Qiao, Adv. Mater. 2014, 26, 2925-2930; b) Y. Zhao, R. Nakamura, K. Kamiya, S. Nakanishi, K. Hashimoto, Nat. Commun. 2013, 4, 2390; c) Z. Y. Lin, G. H. Waller, Y. Liu, M. L. Liu, C. P. Wong, Carbon 2013, 53, 130-136.

[19] T. Y. Ma, S. Dai, M. Jaroniec, S. Z. Qiao, Angew. Chem. Int. Ed. 2014, 53, 7281-7285.

[20] J. Zhang, Z. Zhao, Z. Xia, L. Dai, Nat. Nanotechnol. 2015, 10, 444-452.

[21] X. Lu, W.-L. Yim, B. H. R. Suryanto, C. Zhao, J. Am. Chem. Soc. 2015 137, 2901-2907.

[22] D. V. Kosynkin, A. L. Higginbotham, A. Sinitskii, J. R. Lomeda, A. Dimiev, B. K. Price, J. M. Tour, Nature 2009, 458, 872-875.

[23] Y. G. Li, W. Zhou, H. L. Wang, L. M. Xie, Y. Y. Liang, F. Wei, J. C. Idrobo, S. J. Pennycook, H. J. Dai, Nat. Nanotechnol. 2012, 7, 394-400.

[24] A. Manceau, K. L. Nagy, Geochim. Cosmochim. Acta 2012, 99, 206-223.

[25] D. Wang, H. L. Xin, R. Hovden, H. Wang, Y. Yu, D. A. Muller, F. J. DiSalvo, H. D. Abruna, Nat. Mater. 2013, 12, 81-87.

[26] A. Chuvilin, E. Bichoutskaia, M. C. Gimenez-Lopez, T. W. Chamberlain, G. A. Rance, N. Kuganathan, J. Biskupek, U. Kaiser, A. N. Khlobystov, Nat. Mater. 2011, 10, 687-692.

[27] G. Zheng, Q. Zhang, J. J. Cha, Y. Yang, W. Li, Z. W. Seh, Y. Cui, Nano Lett. 2013, 13, 1265-1270.

[28] a) S. Chen, J. Duan, M. Jaroniec, S. Z. Qiao, Adv. Mater. 2014, 26, 2925-2930; b) Z. Wen, S. Ci, Y. Hou, J. Chen, Angew. Chem. Int. Ed. 2014, 53, 6496-6500; c) C. Tian, Q. Zhang, B. Zhang, Y. Jin, J. Huang, D. S. Su, F. Wei, Adv. Funct. Mater. 2014, 24, 5956-5961; d) G. L. Tian, M. Q. Zhao, D. Yu, X. Y. Kong, J. Q. Huang, Q. Zhang, F. Wei, Small 2014, 10, 2251-2259.

[29] D. R. Lide, Handbook of Chemistry and Physics, CRC Press, Inc., 2000.

[30] Y. Meng, D. Voiry, A. Goswami, X. Zou, X. Huang, M. Chhowalla, Z. Liu, T. Asefa, J. Am. Chem. Soc. 2014, 136, 13554-13557.

[31] T. Maiyalagan, K. A. Jarvis, S. Therese, P. J. Ferreira, A. Manthiram, Nat. Commun. 2014, 5, 3949.

[32] H. Kim, K. Lee, S. I. Woo, Y. Jung, Phys. Chem. Chem. Phys. 2011, 13, 17505-17510. 


\section{WILEY-VCH}

[33] a) Y. Y. Liang, Y. G. Li, H. L. Wang, J. G. Zhou, J. Wang, T. Regier, H. J. Dai, Nat. Mater. 2011, 10, 780-786; b) Y. J. Sa, K. Kwon, J. Y. Cheon, F. Kleitz, S. H. Joo, J. Mater. Chem. A 2013, 1, 9992-10001.

[34] M. R. Gao, W. C. Sheng, Z. B. Zhuang, Q. R. Fang, S. Gu, J. Jiang, Y. S. Yan, J. Am. Chem. Soc. 2014, 136, 7077-7084.

[35] M. Huynh, D. K. Bediako, D. G. Nocera, J. Am. Chem. Soc. 2014, 136, 6002-6010.

Received: ((will be filled in by the editorial staff))

Revised: ((will be filled in by the editorial staff))

Published online: ((will be filled in by the editorial staff)) 


\begin{abstract}
Click here to access/download
Supporting Information
SI.docx

\section{Click here to access/download
Supporting Information
SI.docx

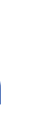

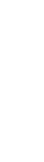
Sl.docx

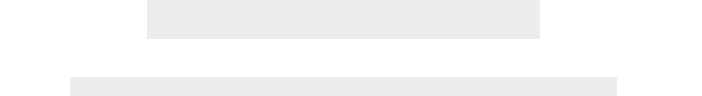

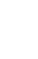

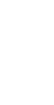


Click here to access/download Production Data Abdel Graphical abstract 10 15.docx 


\section{Click here to access/download Production Data

\author{
Figure 1.tif \\ (n)

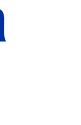

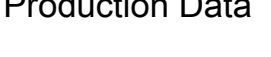

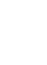

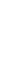


Click here to access/download
Production Data
Figure 2.tif Click here to access/download
Production Data
Figure 2.tif Click here to access/download
Production Data
Figure 2.tif

\begin{abstract}
Production Data

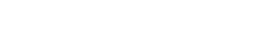

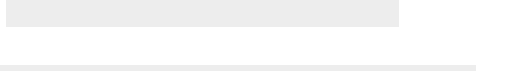

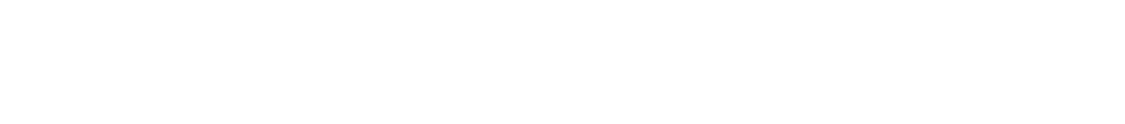

.

Production Data
Figure 2.tif
Click here to access/download 
Production Data

\begin{abstract}
Click here to access/download
Production Data
Figure 3.tif
Click here to access/download
Production Data
Figure 3.tif Click here to access/download
Production Data
Figure 3.tif

\section{政} Click here to access/download
Production Data
Figure 3.tif
\end{abstract}

(

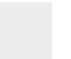




\section{Production Data}

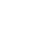
Click here to access/download
Production Data
Click here to access/download
Production Data Figure 4.tif Click here to access/download
Production Data

. 
Click here to access/download
Production Data
Figure 5.tif

Click here to access/download
Production Data
Figure 5.tif Click here to access/download
Production Data
Figure 5.tif

Click here to accesss/download
Production Data
Figure 5. tif

Production Data

Click here to access/download
Production Data
Figure 5.tif

\section{(n)

(1)

Click here to access/download
Production Data
Figure 5.tif

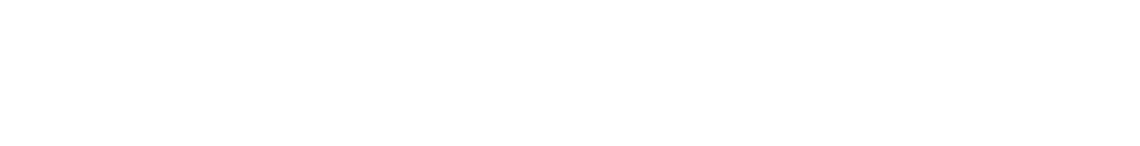

(n)

Click here to access/download
Production Data
Figure 5.tif

Click here to access/download
Production Data
Figure 5.tif

列 
Click here to access/download
Production Data
Figure 6.tif

Click here to access/download
Production Data
Figure 6.tif Click here to access/download
Production Data
Figure 6.tif

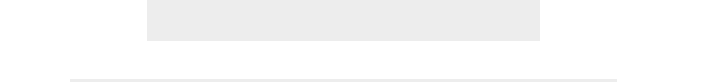 \\ +}

Production Data

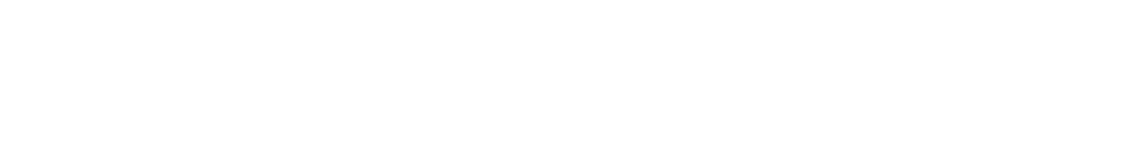

.

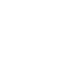

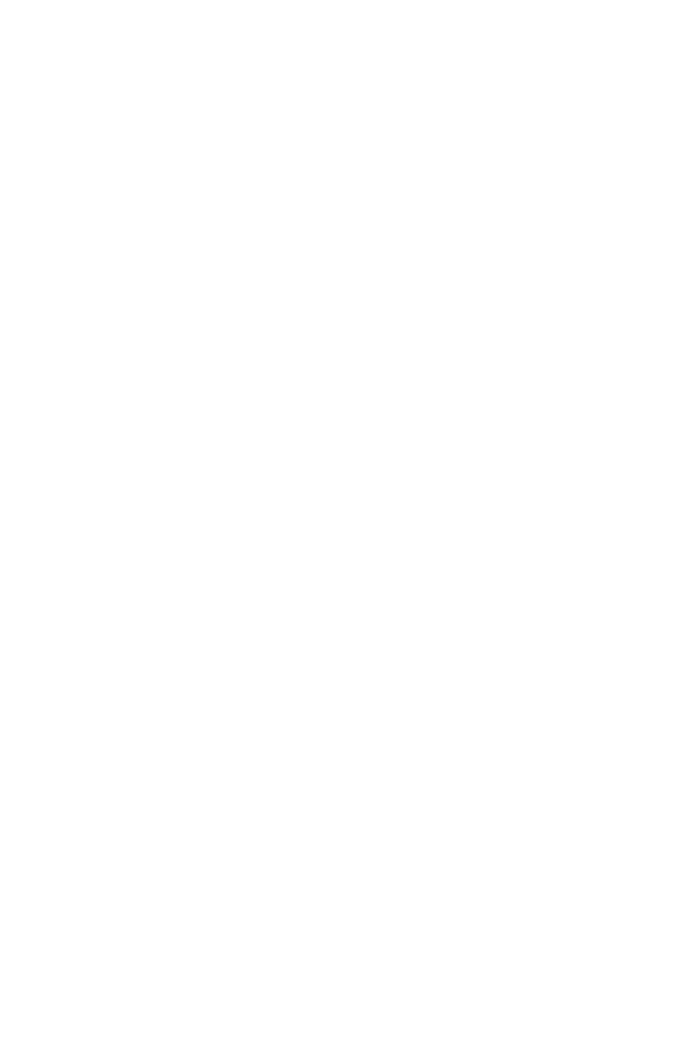


Click here to access/download
Production Data
Figure 7.tif

Production Data
Figure 7.tif Production Data
Figure 7.tif

\author{
.
}

Production Data
Figure 7 tif
Click here to access/download
Production Data

Production Data
Figure 7.tif
Click here to access/download
Produdion 
Production Data
Figure 8.tif
Click here to acess/download

Production Data
Figure 8.tif Production Data
Figure 8.tif

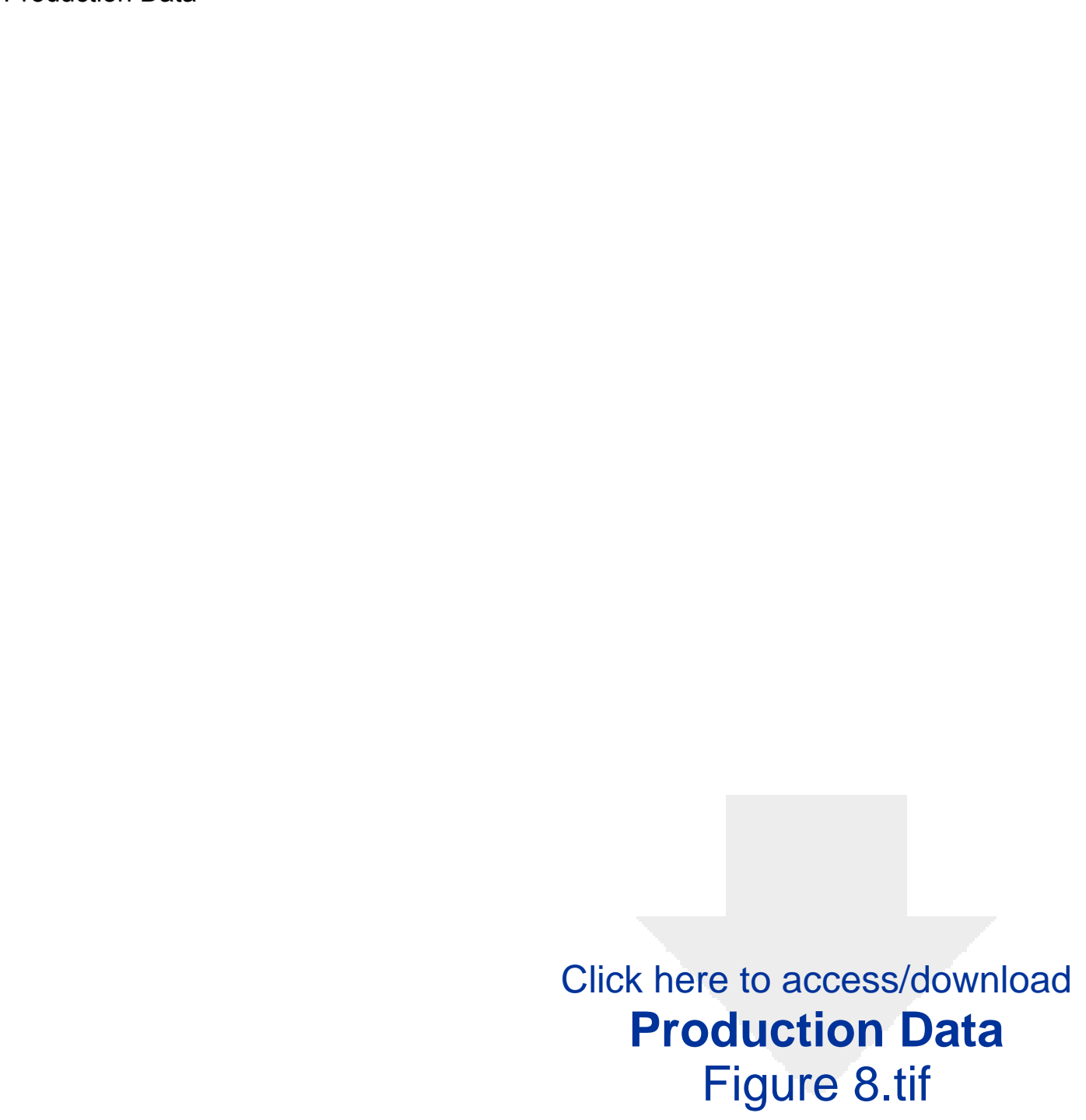

Production Data
Figure 8.tif

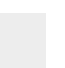


Click here to access/download
Production Data
Figure 9.tif

Click here to access/download
Production Data
Figure 9.tif Click here to access/download
Production Data
Figure 9.tif

Production Data
Figure 9.tif

Production Data
Figure 9. tif
Click here to access/download
Prota

Production Data
Figure 9.tif 
Production Data

\begin{abstract}
Click here to access/download
Production Data
TOC-color CNT.tif
Click here to access/download
Production Data
TOC-color CNT.tif Click here to access/download
Production Data
TOC-color CNT.tif
\end{abstract}

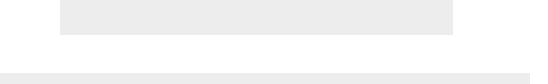

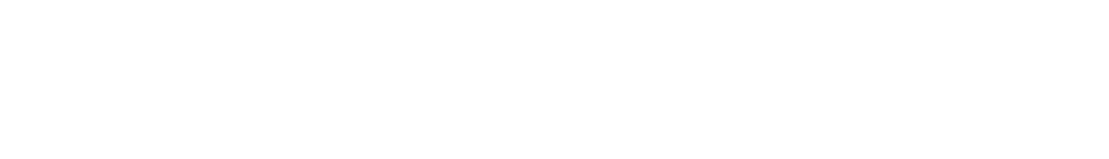

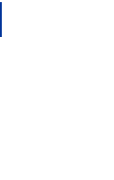

(1) \\ (
}

Production Datis

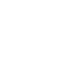

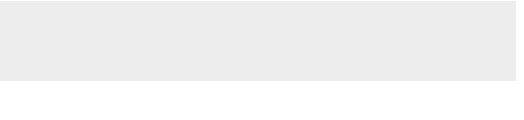

-

(n)

(1)

(1)

.

.

